\title{
Review \\ Personalizing Oncolytic Virotherapy for Glioblastoma: In Search of Biomarkers for Response
}

\author{
Eftychia Stavrakaki, Clemens M. F. Dirven and Martine L. M. Lamfers *(D) \\ Department of Neurosurgery, Brain Tumor Center, Erasmus University Medical Center, \\ 3015 CN Rotterdam, The Netherlands; e.stavrakaki@erasmusmc.nl (E.S.); c.dirven@erasmusmc.nl (C.M.F.D.) \\ * Correspondence: m.lamfers@erasmusmc.nl
}

check for updates

Citation: Stavrakaki, E.; Dirven,

C.M.F.; Lamfers, M.L.M.

Personalizing Oncolytic Virotherapy for Glioblastoma: In Search of Biomarkers for Response. Cancers 2021, 13, 614. https://doi.org/ $10.3390 /$ cancers13040614

Academic Editors: Antonio Marchini, Carolina S. Ilkow and Alan Melcher

Received: 28 December 2020

Accepted: 29 January 2021

Published: 4 February 2021

Publisher's Note: MDPI stays neutral with regard to jurisdictional claims in published maps and institutional affiliations.

Copyright: (c) 2021 by the authors. Licensee MDPI, Basel, Switzerland. This article is an open access article distributed under the terms and conditions of the Creative Commons Attribution (CC BY) license (https:/ / creativecommons.org/licenses/by/ $4.0 /)$.
Simple Summary: Glioblastoma (GBM) is the most frequent and aggressive primary brain tumor. Despite multimodal treatment, the prognosis of GBM patients remains very poor. Oncolytic virotherapy is being evaluated as novel treatment for this patient group and clinical trials testing oncolytic viruses have shown impressive responses, albeit in a small subset of GBM patients. Obtaining insight into specific tumor- or patient-related characteristics of the responding patients, may in the future improve response rates. In this review we discuss factors related to oncolytic activity of the most widely applied oncolytic virus strains as well as potential biomarkers and future assays that may allow us to predict response to these agents. Such biomarkers and tools may in the future enable personalizing oncolytic virotherapy for GBM patients.

Abstract: Oncolytic virus (OV) treatment may offer a new treatment option for the aggressive brain tumor glioblastoma. Clinical trials testing oncolytic viruses in this patient group have shown promising results, with patients achieving impressive long-term clinical responses. However, the number of responders to each OV remains low. This is thought to arise from the large heterogeneity of these tumors, both in terms of molecular make-up and their immune-suppressive microenvironment, leading to variability in responses. An approach that may improve response rates is the personalized utilization of oncolytic viruses against Glioblastoma (GBM), based on specific tumor- or patientrelated characteristics. In this review, we discuss potential biomarkers for response to different OVs as well as emerging ex vivo assays that in the future may enable selection of optimal OV for a specific patient and design of stratified clinical OV trials for GBM.

Keywords: oncolytic viruses; glioblastoma; clinical trials; biomarkers; personalized oncolyticvirotherapy

\section{Introduction}

Oncolytic viral therapy or virotherapy is a form of immunotherapy showing promising results for cancers with poor prognosis [1]. In this approach, oncolytic viruses (OVs) are employed to kill tumor cells, while in parallel stimulating an anti-tumor immune response [2]. OVs exhibit either natural tropism to malignant cells or their genome is altered to confer them higher specificity for malignant cells [3]. Viruses from ten different families (Adenoviridae, Herpesviridae, Paramyxoviridae, Reoviridae, Retroviridae, Picornaviridae, Parvoviridae, Poxviridae, Rhabdoviridae, Alphaviruses) have thus far been utilized as oncolytic virus platforms in clinical trials for various cancer types [2].

One deadly type of cancer is glioblastoma multiforme (GBM), the most common and aggressive primary brain tumor [4]. The standard treatment consists of maximal safe surgical resection followed by radiotherapy plus concomitant and adjuvant temozolomide chemotherapy. However, the median overall survival among all GBM patients is less than one year, and only 15 months in patients receiving complete standard treatment with 3-year survival being less than $10 \%[5,6]$. In the past decades, numerous therapeutic approaches 
have been tested in clinical trials, with disappointing outcomes. The main obstacles in treating GBM include its infiltrative growth, its intrinsic resistance to chemo- and radiotherapy, its notorious intratumoral heterogeneity with dynamic changes in subclones facilitating treatment escape, its protected location behind the blood-brain-barrier and the immunological 'cold' microenvironment of these tumors. These hurdles to more conventional therapies, as well as the dismal prognosis of GBM patients, have encouraged scientists and clinicians to develop and evaluate the local application of various types of oncolytic viruses in this patient group. Table 1 summarizes the most commonly applies OVs in GBM trials. The OVs differ in their primary attachment molecules to host receptors as well as in the source of their tumor selectivity, which may be derived from a natural tropism to cancer cells or by genetic engineering.

Table 1. Characteristics of the most commonly used Oncolytic viruses (OVs) in glioblastoma multiforme (GBM) clinical trials.

\begin{tabular}{|c|c|c|c|c|c|}
\hline Family & Genome & OV Examples & Genetic Engineering & Entry Receptor & Tumor Specificity \\
\hline & & HSV1716 & ICP34.5-deleted & $\begin{array}{l}\text { HVEM, 3-O-sulfated } \\
\text { heparin sulfate and nectin-2 }\end{array}$ & $\begin{array}{l}\text { Defects in the p16/Rb, PKR or } \\
\text { interferon pathways [7] }\end{array}$ \\
\hline \multirow{3}{*}{ Herpesvirus } & \multirow{3}{*}{ dsDNA } & G207 & $\begin{array}{l}\text { ICP34.5 and ICP6 } \\
\text {-deleted mutant oHSV }\end{array}$ & $\begin{array}{l}\text { HVEM, 3-O-sulfated } \\
\text { heparin sulfate and nectin-2 }\end{array}$ & $\begin{array}{l}\text { Defects in the p16/Rb, PKR or } \\
\text { interferon pathways [8] }\end{array}$ \\
\hline & & $\mathrm{G} 47 \Delta$ & $\begin{array}{l}\text { ICP34.5, ICP6 and } \alpha 47 \\
\text {-deleted mutant oHSV }\end{array}$ & $\begin{array}{l}\text { HVEM, 3-O-sulfated } \\
\text { heparin sulfate and nectin-2 }\end{array}$ & $\begin{array}{l}\text { Defects in the p16/Rb, PKR or } \\
\text { interferon pathways [9] }\end{array}$ \\
\hline & & rQnestinHSV-1 & $\begin{array}{l}\text { ICP34.5-deleted mutant oHSV, in } \\
\text { which } \gamma 134.5 \text { gene was reinserted } \\
\text { under control of nestin promoter }\end{array}$ & $\begin{array}{l}\text { HVEM, 3-O-sulfated } \\
\text { heparin sulfate and nectin-2 }\end{array}$ & Expression of nestin [10] \\
\hline \multirow{2}{*}{ Adenovirus } & \multirow{2}{*}{ dsDNA } & Onyx-015 & $\begin{array}{l}\text { E1B-55k and E3B -deleted mutant } \\
\text { group C adenovirus }\end{array}$ & CAR & $\begin{array}{l}\text { Defects in p53 pathway, defects in } \\
\text { cell cycle, late viral } \\
\text { RNA export [11] }\end{array}$ \\
\hline & & delta24-RGD & $\begin{array}{l}\text { 24-base pair deletion in the E1A } \\
\text { gene and insertion of an RGD } \\
\text { sequence in the viral knob }\end{array}$ & $\begin{array}{c}\mathrm{CAR}, \alpha \mathrm{v} \beta 3 \text { and } \alpha \mathrm{v} \beta 5 \\
\text { integrins }\end{array}$ & Defects in Rb pathway [12] \\
\hline \multirow[t]{2}{*}{ Paramyxoviridae } & \multirow[t]{2}{*}{$(-)$ ssRNA } & MV-CEA & $\begin{array}{l}\text { Edmonston (MV-Edm) vaccine } \\
\text { strain with insertion of the human } \\
\text { carcinoembryonic antigen gene }\end{array}$ & CD46, nectin-4, SLAM & $\begin{array}{l}\text { Overexpression of CD46, defects } \\
\text { in the interferon pathway [13] }\end{array}$ \\
\hline & & NDV & Natural tropism & Sialic acids & $\begin{array}{l}\text { Defects in the } \\
\text { interferon pathway [14] }\end{array}$ \\
\hline Reovirus & dsRNA & R124 & Natural tropism & JAM-A, Nogo Receptor NgR1 & $\begin{array}{l}\text { Defects in the Ras } \\
\text { signaling pathway [15] }\end{array}$ \\
\hline Picornaviridae & $(+)$ ssRNA & PVSRIPO & $\begin{array}{l}\text { Poliovirus type } 1 \text { (Sabin) vaccine } \\
\text { with replacement of the internal } \\
\text { ribosomal entry site (IRES) with } \\
\text { the human rhinovirus type } 2 \text { IRES }\end{array}$ & CD155 & Overexpression of CD155 [16,17] \\
\hline Parvovirus H1 & ssDNA & $\begin{array}{l}\text { Parvovirus } \\
\text { H-1PV }\end{array}$ & Natural tropism & Sialic acids & $\begin{array}{c}\text { Defects in interferon pathway, } \\
\text { defects in cell } \\
\text { proliferation pathways [18] }\end{array}$ \\
\hline
\end{tabular}

In a recent review, Chiocca et al. summarized the findings [19] from all the recent GBM oncolytic virotherapy trials and illustrated that a subgroup of GBM patients responds exceptionally well to OV treatments, with survivors at 36-months, and with some patients exhibiting long term remission $[20,21]$. This phenomenon has also been observed in OV trials for other cancer types. For instance, a phase II clinical trial employing an oncolytic herpes simplex virus 1 for stage IIIC or IV melanoma showed $26 \%$ overall response [22].

These observations raise the question: would the responding patients have been the same individuals if they had been treated with any other OV, or are we looking at responders to a specific OV? In other words, is the elicited immune response a generalized one for all types of OVs, or does each OV elicit a specific anti-tumor immune response? The latter would suggest that response rates may be significantly increased if we are able to define which OV is best suited for a particular patient. Identification of robust predictive biomarkers for $\mathrm{OV}$ response would allow future design of stratified clinical trials employing multiple OV strains. The replication efficiency of the virus is thought to be of importance for generation of the subsequent inflammatory and anti-tumor responses. Moreover, host immune status is also expected to contribute to the efficacy of OV treatment. This review, therefore, focuses on tumor and host resistance mechanisms to viral infection, 
replication and oncolysis and discusses potential biomarkers that have previously been reported in relation to sensitivity or resistance to the most frequently employed OVs in preclinical and clinical GBM research.

\section{Glioblastoma}

\subsection{Heterogeneity, Stem Cells and Therapy Resistance}

Common molecular abnormalities involved in the evolution of glioblastomas include aberrations in the oncogenes (EGFR, PDGF and its receptors) and tumor suppressor genes (p16INK4a, p14ARF, PTEN, RB1, and TP53), which are often observed in other human cancers as well [23]. GBM is also characterized by inter-tumoral heterogeneity, which is highlighted by the classification of GBMs into three subgroups: proneural, classical and mesenchymal [24,25]. Each subtype is characterized by specific gene expression patterns and molecular abnormalities, resulting in different clinical treatment outcomes [25,26]. Proneural subtype has the most favorable prognosis among the three subtypes; aberrations in the isocitrate dehydrogenase 1 (IDH1) gene and the platelet-derived growth factor receptor A (PDGFRA) define this subgroup. The classical subgroup is characterized by the amplification of EGFR, lack of TP53 mutations and often with homozygous CDKN2A deletions [26]. Lastly, the mesenchymal subtype is the most aggressive and it is characterized by aberrations in the neurofibromin 1 (NF1) and PTEN genes [23]. It is also characterized by a pro-inflammatory environment compared with the other subtypes [27]. It was hypothesized that one underlying cause for this was the higher incidence of tumorassociated antigens (TAAs), however this could not be proven, as specific tumor antigens are expressed in each subtype [27]. Nevertheless, this classification has not led to altered or adapted treatment approaches [28,29].

Apart from intertumoral heterogeneity, intra-tumoral heterogeneity poses another therapeutic obstacle in treatment of GBM, allowing escape of subclones from (targeted) therapies and driving treatment resistance. This heterogeneity was captured by genomewide and single cell RNA studies, which showed tumor cells with different transcriptional profiles within the same tumor [30,31]. In addition, it was shown that within the same tumor, different subtypes can coexist, highlighting the heterogeneity that characterizes GBM [31]. In another study, paired primary and recurrent tumor tissue samples were analyzed to determine the persistence of possible drug targets. The results showed that the molecular targets between primary and recurrent tumors changed by $90 \%$ [32]. This may explain the failure of drugs that target specific molecular mutations in GBM, such as the EGFR [33].

Eventually, most of the patients experience tumor relapse due to therapeutic resistance [29]. This therapeutic resistance is mainly attributed to glioblastoma stem cells (GSCs), which activate DNA repair mechanisms to promote survival after chemo- and radiotherapy [34]. Additionally, outgrowth of resistant subclones and downregulation of targeted molecules contribute to drug resistance. Furthermore, the highly infiltrative nature of GSCs makes total surgical resection of the tumor impossible [35]. The remaining and/or treatment-resistant clones will eventually generate functional vessels for the nutrient transport and develop tumor recurrence [34].

\subsection{GBM Microenvironment: Local Immunosuppressive Mechanisms}

Glioblastoma arises in the central nervous system (CNS) [36], which is an immunologically distinct site. In the past, the CNS was considered an immune privileged site, due to its unique properties. For instance, the blood brain barrier, which tightly regulates the transportation of the immune cells from the periphery to the CNS; the lack of antigen presenting cells in a non-inflamed state; and more importantly the lack of a classic lymphatic system [37-39]. The concept of CNS being immune privileged has now been revised. Recent studies have shown that antigens derived from the CNS can efficiently elicit an immune response [40]. More importantly, Louveau et al. [41] discovered a functional lymphatic system, parallel to the dural sinuses, a possible route of transportation of antigen-presenting 
cells to the deep cervical lymph nodes, where they can present CNS-derived antigens and prime $\mathrm{T}$ cells. These recent studies have provided evidence that CNS-derived antigens can mount a vigorous immune response, offering ground to investigate immunotherapy approaches for GBM.

The GBM environment is characterized by the high influx of tumor-associated macrophages (TAMs). In a non-inflamed state, the myeloid composition of the CNS consists of the tissue-resident macrophages that arise from the yolk sac, the microglia [42]. However, in GBM, the microenvironment is comprised mainly of a mixture of microglia and infiltrating monocytes from the periphery. Glioma cells produce a milieu of monocyte chemoattractant proteins along with other factors, leading to disruption of the blood-brain barrier and facilitating recruitment of monocytes from the periphery [43]. When monocytes arrive at the tumor site, glioma cells drive their polarization to an immunosuppressive M2 phenotype [44,45]. These M2-like TAMs promote tumor growth and migration as well as the immune invasion by hampering the adaptive immunity $[44,46,47]$. TAMs are the most abundant immune cell population in GBM and can consist up to 50\% of the GBM tumor mass. Their importance in tumor growth is highlighted by the correlation between increased TAM numbers and worse prognosis in GBM patients; furthermore, TAM infiltration has been associated with the mesenchymal subtype of GBM, being the most aggressive one [48,49].

Another feature that facilitates the local immune suppression in GBM is T cell dysfunction. Severe T cell exhaustion is observed in GBM, which is characterized by upregulation of expression of co-inhibitory molecules like PD-1, LAG-3 and TIM-3 [50]. Furthermore, an increase in numbers of the regulatory T cells (Tregs), which can suppress the antigenspecific T cells, was found in high grade gliomas compared to low grade gliomas [51]. The recruitment of Tregs at the tumor site is mainly facilitated by the production of the attractant indoleamine 2,3 dioxygenase (IDO) by gliomas [52]. Another facet that contributes to the "cold" tumor microenvironment is the relatively low mutational burden of GBM cells, associated with limited expression of neoantigens $[53,54]$. Taken together, GBM has all the characteristics of a tumor with low immunogenicity. The M2-like macrophages that are abundant at the tumor site, the dysfunctional $\mathrm{T}$ cells and the low neoantigen expression are some of the barriers that we need to overcome to design successful immunotherapies.

Considering all of the above, a therapeutic strategy that is not hindered by specificity for a single molecular target or differentiation state of tumor cells, that is delivered locally in a single surgical intervention, hence bypassing the BBB, that is self-perpetuating in its antitumor activity, and which can overcome the immune-suppressive tumor microenvironment, may offer opportunities for achieving therapeutic responses in glioblastoma patients. Oncolytic viruses offer such a treatment strategy.

\section{Factors Affecting OV Therapy in GBM}

Several oncolytic virotherapy clinical trials have shown impressive and durable responses in a subset of patients, indicating that OVs might be a very promising therapeutic tool for treating GBM. The establishment of an efficient viral infection, lysis of tumor cells, viral spreading and anti-tumor immune activation, all depends on multiple factors (Figure 1). It is therefore conceivable that we may improve OV efficacy if we take these factors into account when selecting patients for treatment. 


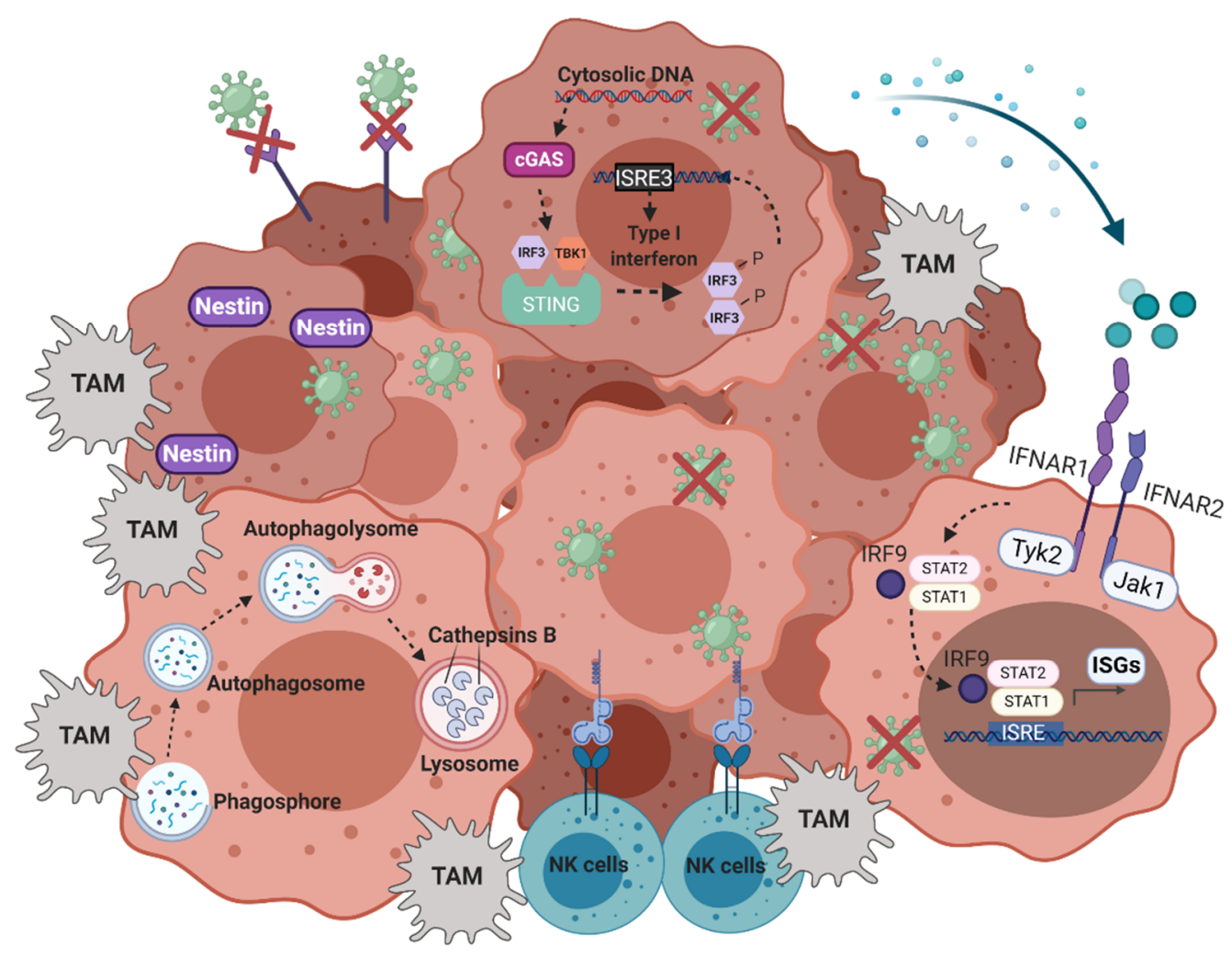

Figure 1. OV restriction mechanisms of GBM tumors. Infiltration of NK cells and tumor-associated macrophages (TAMs) at the tumor site, activation status of autophagy, expression of viral entry molecules and viral sensors (e.g., cGAS-STING) that lead to constitutive active type I interferon pathways, all could hamper the OV replication and oncolysis. Furthermore, cathepsin B expression and expression of specific proteins that drive specific tumor replication (e.g., nestin) could determine the OV efficacy. Created with BioRender.com.

\subsection{Viral Entry Molecule Expression}

Tumor cell infection and oncolysis are a prerequisite for mounting an inflammatory response in the tumor microenvironment and ultimately generating an anti-tumor immune response. This depends on the cell entry possibilities for the virus. As GBM cells are not the natural host cells for entry of most viruses, low levels or even lack of receptor molecules on these cells can form the first obstacle to virotherapy. It has been shown that tremendous inter-tumoral variability exists in expression levels of specific adenovirus and reovirus entry molecules on patient-derived GBM cells $[55,56]$. As a result, various retargeting strategies have been applied to overcome such limitations, including EGFR and integrin retargeting of OVs [57]. Therefore, OV efficacy could potentially be enhanced by stratification of patients based on expression of specific viral receptor molecules in their tumors.

\subsection{Status of Oncogenic Signaling Pathways Affected in Glioblastoma}

Many OVs applied in glioma studies are genetically engineered or have naturally evolved to exploit oncogenic signaling pathways in cancer cells, such as the Ras, $\mathrm{Rb}$, p53 or nucleotide synthesis pathways [58]. Therefore, OV efficacy could potentially be enhanced by stratification of patients based on activation status or presence of mutations in targeted pathways.

Another targeting approach is by the insertion of tumor-specific promoters to drive specific viral replication in tumor cells and avoid toxicity to normal tissue [59]. Various promoter candidates have been applied to design tumor-specific promoter-driven OVs, including nestin, survivin, cyclooxygenase-2 (COX-2), C-X-C chemokine receptor type 4 (CXCR4), hypoxia inducible factor-1 (HIF-1) and telomerase [10,60-63]. Considering the 
intertumoral heterogeneity in transcription profiles of GBM, it would be expected that the response to such OVs might vary between GBM subtypes. One could hypothesize that GBM with proneural features might be more sensitive to viruses targeting cells expressing neuronal progenitor genes (e.g., nestin), whereas tumors of mesenchymal subtype may be more sensitive to viruses in which replication is driven by the inflammation-activated COX-2 or CXCR4 promoter [62-64].

\subsection{Innate Anti-Viral Responses}

Upon cell entry, antiviral host defenses may be activated that counteract a productive lytic cycle and progeny production. There is a plethora of innate sensors that could lead to clearance of the infected cell and halt the viral spreading, leading to resistance to OV therapy. As soon as the cell is infected, the viral pathogen-associated molecular patterns (PAMPs) are sensed by pattern recognition receptors (PRRs). These PRRs include Toll-like receptors (TLRs) [65], RIG-I-like receptors (retinoic acid-inducible gene-I-like receptors, RLRs) [66], Ctype lectin receptors (CLRs) [66], oligomerization domain containing receptors \{(NOD-like receptors (NLRs)\} [66], cyclic GMP-AMP synthase (cGAS) [67] and absent in melanoma 2 (AIM2)-like receptors (ALRs) [68]. The recognition of the viral PAMPs from the host PRRs results in interferon type I (IFN $\alpha$, IFN $\beta$, IFN- $\varepsilon$, IFN- $\kappa$, IFN- $\omega$, IFN- $\delta$, IFN- $\zeta$ and IFN- $\tau$ ) and interferon type III (IFN- $\lambda \varsigma$ ) production, as well as the expression of interferon stimulated genes (ISGs) and other proinflammatory cytokines and chemokines [69,70].

Although the aforementioned PRRs have been extensively studied, not many studies have attempted to correlate their overexpression in tumor cells with OV resistance; but rather with the aftermath of the recognition, the antiviral interferon pathways. However, a few studies have implicated the cytosolic DNA sensing pathway to oncolytic herpes virus-1 resistance (see below). The main sensor of dsDNA in the cytoplasm is the cGAS, which recognizes dsDNA viruses and reverse transcribing RNA viruses like HIV-1. As soon as cGAS is activated, it synthesizes cGAMP which activates the adaptor protein stimulator of interferon genes (STING) [71]. Stimulation of STING leads to the activation of IRF3 and $\mathrm{NF}_{K} \mathrm{~B}$ [71]. Interferon gamma inducible protein 16 (IFI16) is another sensor of dsDNA that signals via STING to activate IRF3 and NFKB resulting in IFN $\beta$ production [72].

Ultimately, viral detection by the aforementioned sensors will lead to the activation of host defenses such as the production of type I and type III interferons. These have distinct receptors, however, both activate a signaling cascade via receptor-associated protein tyrosine kinases Janus kinase 1 (JAK1) and tyrosine kinase 2 (TYK2), which activate the activator of transcription 1 (STAT1) and STAT2, which subsequently form a complex with the IFN regulatory factor 9 (IRF9), the ISGF3 complex [73]. This complex translocates to the nucleus, resulting in the expression of more than 300 ISGs and pro-inflammatory molecules and establishing an anti-viral state in the infected cell $[74,75]$. The cytokine and chemokine milieu produced by the infected cell also acts in a paracrine manner to induce an ISG-mediated anti-viral state in the (uninfected) adjacent cells. Some of these ISGs, such as GTPase myxovirus resistance 1 (MxA), ribonuclease L (RNaseL) and protein kinase $\mathrm{R}$ (PKR) have direct antiviral activity. For instance, MxA monomers reside in the cytoplasm and upon binding to viral components can degrade them [76]. PKR regulates a plethora of signaling pathways and its role in antiviral response and inhibition of host translation is considered crucial upon virus infection [76].

The anti-viral IFNs are major determinants of OV efficacy. Many OVs exploit the IFN pathway defects to successfully replicate in tumor cells. For instance, it has been shown that STING pathway is correlated with oncolytic herpes virus-1 resistance (see below). However, new evidence shows that this advantage in viral replication may not correlate with tumor eradication in vivo [77]. This may be explained by the inability of oncolytic viruses to induce immunogenic cell death in STING-deficient tumor cells, thus hampering the induction of innate and adaptive immunity [78]. Identifying specific defects in the IFN pathway that may 'assist' the viral replication without harming the induction of antitumor immunity, could lead to identification of predictive biomarkers for OV sensitivity. 


\subsection{The Autophagic Response to Viral Infections}

There is growing evidence that the role of autophagy in the infectious cycle of many viruses is critical. Autophagy is an evolutionary conserved adaptive process in which the cells attempt to maintain their homeostasis $[79,80]$. It can be triggered by different types of stress, such as hypoxia, nutrient deprivation and infection [81]. The role of autophagy is to remove detrimental cytosolic material such as protein aggregates and damaged organelles. During this process, a phagophore engulfs cytosolic material to form an autophagosome, which subsequently fuses with a lysosome to degrade its cytoplasmic content [81].

Autophagy is activated by the infected cell to degrade and remove the virions from the cell, a process called xenophagy [82]. TLRs, RLRs and cGAS signaling pathways, among others, lead to autophagy activation to enhance the interferon production and create an anti-viral milieu [83]. Notably, plasmacytoid dendritic cells (pDCs) which lack the autophagy protein 5 (Atg5) showed decreased TLR7-dependent IFN $\alpha$ and IL-12 production after VSV and Sendai virus infection, indicating the importance of autophagy for mounting an anti-viral response [84]. Additionally, autophagy was shown to have anti-viral effects against Sindbis virus and Rift Valley Fever Virus infection $[85,86]$. On the other hand, many viruses have developed mechanisms to exploit autophagy in favor of their viral replication. For example, herpesvirus and dengue virus were shown to enhance autophagy to promote cell survival in order to establish a successful infection and enhanced viral replication $[87,88]$. Moreover, rapamycin, an autophagy inducer, was shown to increase the viral replication of various oncolytic viruses in tumor cells, including adenovirus, reovirus, poliovirus, herpes virus, NDV and myxoma virus [89-94]. In line with these findings, it was shown that knocking out two key autophagy genes (ATG5 or ATG10) impaired virus-induced lysis of cancer cells by a modified oncolytic adenovirus (delta24-RGD) [95]. Furthermore, co-treatment with Everolimus, a rapamycin derivative, and delta24-RGD enhanced autophagic dependent cell death in an in vivo glioma model [96].

The double-sided role of autophagy in oncolytic virus efficacy has captured the attention of the research community and it has been extensively reviewed $[97,98]$. The results thus far suggest that, for certain OVs, the tumor cells' ability to activate autophagy can contribute to the degree of viral replication, and ultimately the therapeutic efficacy of the viral treatment.

\section{Potential Biomarkers for Sensitivity to Oncolytic Viruses}

The different OV strains employed in GBM immunotherapy utilize different cell entry receptors of entry and their cell killing mechanisms are distinct from each other. Furthermore, each OV strain triggers the host responses in diverse ways. Available in vitro and in vivo data provides numerous leads to pathways and molecules involved in OV sensitivity or resistance. OV trials are increasingly incorporating trial-associated (immune) monitoring studies to gain insight into the in situ mechanisms involved in clinical OV therapy. Such valuable data may yield relevant information for identifying potential biomarkers related to response to OV therapy in GBM.

\subsection{Oncolytic Herpes Simplex Virus}

Oncolytic HSV-1 (oHSV) is an enveloped double-stranded DNA virus that belongs to the alpha-herpesvirus subfamily [99]. It is a neurotropic virus and therefore requires engineering for tumor-restricted replication [100]. Modified oHSV-1 variants that have been tested in glioma patients are G207, G47 $\Delta$, HSV1716 and rQNestin-34.5 [9]. Safety and feasibility of local oHSV injection in GBM was shown in two phase 1 trials testing G207 and HSV1716 [7,8]. However, in both studies viral replication was detected in only a few patients; 3 out of 6 and 2 out of 12 patients, respectively. These results suggest that the replication of the virus was restricted in some patients. In addition, seroconversion was observed in some patients indicating that the antiviral immune response may have contributed to the rapid clearance of the virus $[7,8]$. In an effort to understand these restricting mechanisms, Peters et al. studied G207 infection in vitro and found glioma stem 
cells (GSCs) to be non-permissive to infection [101]. G207 virus contains mutations in both copies of the $\gamma 34.5$ gene to prevent neurovirulence, however, in GSCs this deletion results in a translational shut down preventing the production of progeny virions [101]. Other oHSV-1 variants designed to express the $\gamma 34.5$ protein under a tumor-specific promoter such as the rQNestin-34.5, might enhance the oncolytic activity of the virus in GSCs [10].

Another modified HSV-1 is Talimogene laherparepvec (T-VEC) which is the first Food and Drug Administration (FDA) approved oncolytic virus and is indicated for treatment of patients with advanced melanoma [102]. Numerous clinical trials have employed T-VEC, however, no biomarkers for response have been described thus far. In a clinical study in melanoma patients, a favorable outcome was observed in a subgroup of patients with unresectable Stage III or IV M1a disease [103]. Recently, an in vitro study in melanoma cell lines revealed that STING expression can restrict T-VEC-mediated oncolysis and loss of its expression may confer sensitivity to oncolysis [104].

\subsection{Oncolytic Adenovirus}

Adenoviruses are non-enveloped double-stranded DNA viruses [59]. Oncolytic adenoviruses have been extensively explored and utilized in many clinical trials against several cancers [105]. Conditionally replicating adenoviruses (CRAds) have been modified in diverse ways to target oncogenic pathways frequently mutated cancers such as the retinoblastoma $(\mathrm{Rb})$ or the p53 pathway [58,106]. D11520 (ONYX-015) was the first CRAd tested in a phase I clinical trial for recurrent gliomas, in which the safety of local peritumoral injection of the virus was shown [107]. Several possible selectivity mechanisms have been proposed for dI1520, including p53/p14ARF defects, aberrant late mRNA transport and cell cycle disruption, all of which may relate to the functions of the early viral E1B-55k gene which is deleted in this virus [11]. Whether any of these factors can serve as biomarkers for dI1520 response has not been evaluated.

The results of another phase I clinical study against recurrent malignant gliomas using the CRAd delta24-RGD (DNX-2401) were recently published [20]. This OV was engineered to selectively replicate in tumor cells with dysfunctional $\mathrm{Rb}$ pathway, which is the case in approximately $80 \%$ of GBM tumors [12,58]. Impressive anti-tumor effects were found, with $17 \%$ of the treated patients surviving beyond 3 years [20]. Another early clinical trial with this CRAd was conducted in our institute in patients with recurrent GBM (NCT01582516). A subgroup of patients revealed high concentrations of different cytokines in post treatment CSF samples, indicating that delta24-RGD can induce an inflammatory microenvironment, which is potentially key for its therapeutic efficacy [108]. Whether specific cytokines can serve as biomarkers for response requires further investigation.

Very few studies have focused on elucidating the resistance mechanisms in the nonresponder patients in oncolytic adenoviral trials. In one study, it was demonstrated that the IFN signaling pathway was upregulated in Ad5/3- $\Delta 24$-resistant ovarian tumors compared to untreated tumors [109]. Moreover, the authors showed that the MxA, an ISG which is induced by IFN type I or type III signaling could provide a predictive marker for resistance to oncolytic adenoviral therapies $[109,110]$.

Of great interest are the studies that have focused on the pre-treatment immune status of patients receiving oncolytic adenovirus. Specifically, it was shown that chronic inflammation was a negative predictive marker for response to oncolytic adenovirus therapy in different types of cancer [111]. Furthermore, high-mobility group box 1 (HMGB1), a nuclear protein secreted by immune cells and which is associated with a pro-inflammatory state and immunological cell death, could serve as a predictive and prognostic marker for oncolytic virotherapy with adenoviruses. The study suggested that patients with low serum HMGB1 have more robust anti-tumor responses after oncolytic adenovirus therapy [112]. It was hypothesized that a higher pro-inflammatory state as measured by HMGB1, leads to inhibition of viral replication. These results may suggest that the use of immunosuppressants for a limited amount of time during post virus administration, may improve response rates in this subgroup of patients. 
Lastly, in a study using pancreatic cell lines it was shown that high expression of cyclin D1 enhances delta24-RGD-induced cytotoxicity [113]. Cyclin D1 activates the cyclindependent kinase 4 and 6 (CDK4 and CDK6), which then phosphorylates the Rb protein resulting in cell cycle progression. Over-expression of cyclin D1 has been observed in many cancer types like head and neck squamous cell carcinomas (HNSCC), pancreatic and breast cancer [114]. In GBM, the highest expression of cyclin D1 was observed in the proneural subtype, which may suggest that this subtype would benefit more from delta24-RGD treatment.

\subsection{Oncolytic Retrovirus}

Replication-competent retroviruses are a relative newcomer to the OV field. These are single-stranded RNA viruses. Originally, retroviruses were applied in gene therapy approaches, however, it was later shown that replication competence of retroviruses can provide a powerful tool for gene delivery of anticancer agents in tumors [115]. Vocimagene amiretrorepvec (Toca 511) is a replicating $\gamma$-retrovirus derived from murine leukemia virus and is engineered to encode a yeast cytosine deaminase (CD) gene [116]. In the presence of the prodrug 5-fluorocytosin (5-FC), CD converts 5-FC to the potent anti-cancer drug 5-fluorouracil (5-FU). The results from a phase I clinical trial for recurrent high-grade gliomas showed that the median survival of the patients $(n=53)$ was 13.6 months with six patients showing complete response [21]. However, in a subsequent phase III study in 403 patients, clinical endpoints were not met [117].

New results from the earlier phase I clinical trial (NCT01470794) were recently published demonstrating that $86 \%$ of the patients that lived $>2$ years had neoantigens deriving from IDH1, PI3K3CA, EGFR, SYNE1 genes. Interestingly, only $26 \%$ of the patients with $<2$ years survival had neoantigens arising from these genes, suggesting that neoantigens arising from driver genes may support Toca+5-FC therapy response. Moreover, the numbers of M0 macrophages and NK cells at the tumor site at the time of treatment were associated with poor response [118]. It is conceivable that these cells contributed to clearance of the virus before its therapeutic effect could take place. Further investigation is needed to establish if the immune composition could serve as a predictive marker and whether this is also the case for other oncolytic viruses.

\subsection{Oncolytic Measles Virus}

Oncolytic measles virus (oMV) has been applied in many Phase I/II clinical trials against numerous types of cancers including ovarian cancer, pancreatic cancer and glioblastoma (GBM) [119]. MV is a single-stranded, negative-sense RNA virus that belongs to the Paramyxoviridae family [120]. The entry of MV is mediated by the attachment of the viral Hemagglutinin $(\mathrm{H})$ protein to three known cell surface receptors; the complement regulatory protein CD46, the signaling lymphocyte activating molecule (SLAM) or nectin-4 [121]. The wild type strains of MV mainly bind to the SLAM receptor, the attenuated MV Edmonston's (MV-Edm) vaccine strains enter through CD46 receptor, while nectin-4 can be used by both wild type and Edm strains [121].

The attenuated MV strains have revealed tropism for infecting and killing glioma cells, due to the overexpression of the entry receptor CD46 on the cell surface of these cells $[13,122]$. Although CD46 is abundantly expressed on glioma cells, facilitating efficient infection, some glioma cell lines show resistance to oncolysis after the viral entry, indicating that other processes can affect its oncolytic efficacy [123].

Indeed, a recent study pinpointed the expression of the interferon-induced transmembrane protein 1 (IFITM1) gene as the responsible ISG for restricting oMV replication in transformed human mesenchymal stromal cells [124]. Additionally, in another study researchers screened eight sarcoma cell lines and found that five of them were susceptible to the oMV. The resistance in the three remaining sarcoma cell lines was attributed to the upregulation of the RIG-I and IFITM1 mRNA expression. Interestingly, it was found that 
resistance could be broken by increasing the multiplicity of infection (MOI) in combination with the pro-drug 5-FC [125].

The fact that oMVs are sensitive to antiviral responses was also highlighted by a translational study from Kurokawa et al. [123]. Specifically, it was shown that mice bearing GBM tumors with defective interferon pathway were more responsive to oMV treatment, producing 387-fold higher infectious progeny virions compared to mice bearing GBM with intact interferon pathway. Moreover, gene expression analysis of tumor samples from GBM patients treated with oMV (NCT00390299) showed an inverse correlation of ISGs expression and viral replication [123].

Taken together, evidence suggests that IFITM1 expression may be a biomarker for resistance to oMV virotherapy for GBM patients and could help stratify the patients in oMV trials. Further research needs to be performed in other tumor types to investigate if this is a pan-cancer biomarker for oMV response.

\subsection{Newcastle Disease Virus (NDV)}

NDV is an avian paramyxovirus with a negative-sense, single-stranded RNA enclosed in its viral envelope. It was thought that some NDV strains have oncolytic properties by taking advantage of the inability of the tumor cells to elicit an anti-viral response due to deficiencies in IFN pathway [14]. Therefore, the search for markers of resistance to NDV-mediated oncolysis have focused on the antiviral pathways.

Krishnamurthy et al. showed that NDV susceptibility was linked to impairment of the type I interferon pathway [126]. Fibrosarcoma cells that were susceptible to NDV infection were unable to induce IFN- $\beta$ production [126]. Specifically, the STAT1 and STAT2 phosphorylation was significantly reduced in the permissive tumor cells, resulting in reduced expression of ISG mRNAs and IFN- $\beta$ [126]. In an approach to overcome resistance, Zamarin et al. engineered an NDV variant expressing an IFN $\alpha$-antagonist, which demonstrated enhanced oncolytic activity in melanoma cell lines compared to the NDV strain without the IFN-antagonist [127].

In contrast with these findings, Mansour et al. revealed that the human non-small-cell lung cancer cell line A549 was susceptible to NDV oncolysis, despite the production of high levels of type I IFN response. It was proposed that the restriction mechanism in NDV oncolysis was based on the expression level of the anti-apoptotic protein Bcl-xl, where over-expression of Bcl-xl correlates with increased sensitivity to NDV [128]. Moreover, it was recently demonstrated that STAT3 inhibition suppresses immunogenic cell death (ICD) by NDV in melanoma tumor cells [129]. Interestingly, Bcl-xl is one of the target genes of active STAT3 [129].

Another potential marker for NDV cytotoxicity is the status of the autophagy pathway. Meng et al. showed in U251 glioma cells that NDV exploits the autophagic machinery to increase its replication. In this study, inhibition of BECLIN-1 or ATG5 gene, which are critical for the autophagosome formation, led to reduced production of NDV [130]. A more recent study showed autophagy modulators act as sensitizers for NDV in drug-resistant lung cancers [131]. On a different note, Puhlmann et al. showed that the oncogenic protein, Rac 1, is essential for NDV replication and it could confer sensitivity to viral replication [132]. Rac1 is a Rho GTPase protein and is involved in processes like cell proliferation and cytoskeleton organization [133]. In GBM, it has been shown that Rac1 is important for maintaining the stemness of GSCs, which may suggest that NDV could potentially be utilized to target the treatment-resistant cancer stem cell clones within GBM [134].

\subsection{Mammalian Orthoreovirus (Reovirus)}

Wild type reovirus has been tested clinically for various types of cancer including GBM, both by local and systemic administration $[135,136]$. Reovirus is a non-enveloped virus with 10 segments of dsRNA enclosed in its capsid. The main receptor that wild type reoviruses use to enter the cells is the junctional adhesion molecule A (JAM-A) [15]. Van den Hengel et al. tested a panel of primary GBM cell cultures, showing that they exhibit a 
large intertumoral variability in JAM-A expression, suggesting that reovirus efficacy may be hampered in low JAM-A expressing tumors [56]. Recently a second receptor was shown to mediate reovirus infection in the central nervous system (CNS), the Nogo receptor $\mathrm{NgR1}$ [137]. The NgR1 expression in GBM cell lines has been established in various studies, however in a recent study it was shown that the $\mathrm{NgR}$ maturation, and thus expression to the cell membrane, is inhibited by transforming growth factor- $\beta$ (TGF- $\beta$ ) 1 , which is highly expressed by GBM cells [138-140]. The cell surface expression of NgR1 in primary GBM cells is yet to be elucidated.

Reovirus' natural tropism to replicate and kill tumor cells makes it an ideal candidate for oncolytic virotherapy. Early on, researchers attempted to elucidate the mechanism of tumor selectivity. It was found that the constitutively active Ras signaling pathway potentiates the reovirus replication via inhibition of PKR [141]. Additional studies have supported that Ras pathway activating mutations enhance reovirus replication [142,143]. Contrary to these findings, Twigger et al. showed that reovirus oncolysis does not depend on the status of EGFR/Ras/MAPK pathway in squamous cell carcinoma primary cell lines [144]. Another factor involved in host cell sensitivity to reovirus is determined by the levels of inhibitors of proteases, such as cathepsin B, that are required to disassemble the virus in the cytoplasm. Inhibition of these proteases restricts disassembly and inhibits viral replication [145].

In a clinical phase I trial for high grade gliomas and brain metastasis, the safety of reovirus after intravenous injection prior to brain surgery was demonstrated. The reovirus capsid $\sigma 3$ protein and the virus RNA detection in tumors varied between the nine trial patients and correlated with the high proliferation index of the tumor cells (Ki67 expression) [136]. The efficacy of reovirus was also evaluated in a clinical trial for non-small cell lung cancer (NCT01708993), in which reovirus (Reolysin) was injected intravenously. A post-hoc analysis of the data obtained from this clinical trial showed a favorable trend for patients with p53 and EGFR mutations [146]. Another clinical trial (NCT01199263) testing oncolytic reovirus in ovarian cancer patients did not show any clinical benefit and authors stated that one explanation could be that only $20 \%$ of the ovarian cancer patients harbor Ras mutations [147].

\subsection{Oncolytic Poliovirus}

Poliovirus is an enterovirus in the Picornaviridae family of single-stranded RNA vi-ruses. A non-pathogenic oncolytic variant was engineered by replacing the internal ribo-somal entry site (IRES) of the poliovirus type 1 (Sabin) vaccine strain with the human rhi-novirus type 2 IRES (PVS-RIPO). The affinity of poliovirus for its cellular receptor CD155, which is upregulated on GBM cells, provides a unique opportunity target these tumors [16]. This approach demonstrated potent anti-glioma activity in mouse models and led to translation to clinical investigation for GBM $[17,148]$. Impressive results were obtained in a clinical phase II trial testing the recombinant nonpathogenic polio-rhinovirus chimera (PVSRIPO), oncolytic virus in 61 patients with recurrent GBM. Twenty-one percent of patients were still alive 36 months after initiation of treatment [149]. The source of this striking response in a subgroup of patients has yet to be elucidated. However, intriguingly, transcriptomic analysis revealed a correlation between low tumor mutational burden, tumor-intrinsic inflammation, and improved survival after PVSRIPO or anti-PD1 immunotherapy in recurrent GBM patients [150]. Further studies are required to confirm whether these characteristics hold predictive biomarker potential.

\subsection{Oncolytic Parvovirus $H-1$}

Oncolytic parvovirus H-1 is a single-stranded DNA rodent protoparvovirus 1 virus [18]. The lack of pre-existing immunity in humans makes parvovirus an interesting oncolytic virus to explore in the clinic [151]. Oncolytic $\mathrm{H}-1$ parvovirus was administered intratumorally and intravenously in recurrent GBM patients in a phase I/IIa trial [152]. Robust immune response in terms of high infiltration of cytotoxic T cells was observed in the 
oncolytic parvovirus patients in this first study. Furthermore, in peripheral blood of the patients, specific $T$ cell responses against glioma and viral antigens were detected [152]. Unlike for many other oncolytic viruses, antiviral type I interferon responses are not evoked by parvovirus infection [152]. Interestingly, parvovirus infection of GBM cells is followed by cathepsin B upregulation [152]. Inhibition of cathepsin B protects the glioma cells from parvovirus oncolysis, highlighting cathepsin B's importance in the parvovirus infection [153].

\subsection{Oncolytic Vaccinia Virus}

Vaccinia virus is a double-stranded DNA virus that belongs to poxvirus family [154]. Its natural tropism to enter the CNS has made it an attractive candidate for systemic delivery in GBM patients [155]. A phase I/II clinical study for GBM patients is currently ongoing (NCT03294486), in which patients are treated systemically with the vaccinia virus TG6002 [156]. Different strains of oncolytic vaccinia virus have been applied for other types of cancer as well and researchers tried to identify predictive response markers [157]. Zloza et al. identified the inhibitory molecule immunoglobulin-like transcript 2 (ILT2) on the cell surface of $\mathrm{T}$ cells, as a potential biomarker for vaccinia virus immunotherapy in melanoma patients. Increased expression of ILT2 on T cells was associated with poor response to oncolytic virotherapy using vaccinia virus [157]. Another study attempted to identify biomarkers associated with resistance to vaccinia virus therapy in hematological malignancies [158]. Genes involved in the ubiquitination pathway, DNA damage response and antigen presentation, among others, were identified and associated with resistance to vaccinia virus-induced oncolysis [158]

\section{Development of Personalized in Vitro Models for OV Selection}

It can be concluded that the interplay between the OVs and tumor cells is very complex and that defining a single biomarker or set of biomarkers predicting efficacy of a specific OV may not be achievable. An alternative approach is the development of patient-specific assays to screen a set of OVs and identify the optimal OV for a particular patient. Such a predictive assay would need to provide information on the efficacy of OV infection, replication, and oncolysis as well as on the immune response that is mounted by the OVs.

At present, in vitro culture models from patient-derived tumors have become the gold standard in drug development research for GBM. Our group has developed a preclinical screening system based on patient-derived low-passage cell cultures under serum-free conditions for preserving the molecular genetic make-up of the parental tumors $[159,160]$. Such screening activities have for example led to the identification of viral sensitizers which enhance the oncolytic activity of delta24-RGD in GBM cells [161]. The screening system was also applied to assess the efficiency of infection, replication and cell killing by four different OVs on a panel of primary glioma cell lines, which revealed tremendous intertumoral heterogeneity in viral sensitivities [56] (and unpublished data). Such panels of molecularly characterized cell cultures may also help identify new markers of sensitivity or resistance to tested OVs.

To gain insight in the relationship between oncolytic efficacy and immune stimulation, a co-culture model of glioma cells and (autologous) immune cell populations, could potentially provide useful insight on the immune response that is triggered after treatment with different OV candidates, as well as on the relationship between infectivity, oncolysis and immune activation. For instance, a co-culture of macrophages and delta24-RGD-infected (and permissive) GSCs revealed a shift of the tumor-supportive macrophages M2 to the pro-inflammatory M1 [108]. Such approaches are also being taken for other forms of cancer. A platform has been established for cancers like colorectal and non-small cell lung in which tumor organoids were co-cultured with autologous $\mathrm{T}$ cells derived from the peripheral blood of the patient [162]. With such model systems, the T cell-mediated cell killing could be evaluated for individual patients after infection with different OVs [162].

However, the establishment of such primary GSC or organoid-immune cell co-cultures is time-consuming and may not yield a robust $\mathrm{OV}$ therapy recommendation within the 
required timeframe. Furthermore, with serial passaging of primary glioma cells, the diverse clones that characterize the GBM tumor cannot be maintained [59]. The establishment of ex vivo 3D tumor model systems directly from fresh tumor tissue may therefore offer a more attractive approach for performing OV screens on the heterogeneous landscape of GBM as such models still retain architecture and cellular composition of the original tumor, including the presence of immune cell infiltrates. We previously reported that fresh tissue derived organotypic multicellular spheroids (OMS) offer a versatile system for studying OV infection, replication and tissue penetration [163]. Similarly, fresh GBM tumor slices have been employed to assess oncolytic myxoma virus efficacy [164]. Other approaches being developed include the culture of fresh tumor cells in slices, on matrices and in microfluidic systems [165-167]. Culturing fresh tissue also has limitations, since the culturing methods generally favor the tumor cells and not the immune cells [168]. Identification of culture conditions supporting all cell populations would also offer an improvement to these models.

Efforts in the field to generate 3D models from fresh tissue under culture conditions that support and recapitulate the unique immune tumor microenvironment are expected to facilitate investigations into both the dynamics of viral infection and replication in tumor cells as well as the effects thereof on local immune responses [169]. Such systems may in the future offer a tool to screen multiple OVs for a specific patient and select the optimal viral treatment within a clinically-relevant timeframe.

\section{Conclusions}

With the translation of oncolytic virotherapy to clinical trials for GBM patients, impressive responses have been documented in small subgroups of patients. To increase these response rates, better understanding of factors affecting viral replication, oncolysis and subsequent immune activation is required for each of the OVs under development. Studies in clinically-relevant in vitro and in vivo models as well as trial-associated immune and tumor monitoring studies are crucial for defining these factors and are expected to offer leads for stratification of patients in future OV trials.

Based on current literature reviews, we have identified factors related to the sensitivity of GBM tumors for specific OVs including the expression of the viral entry molecules, activation state of (cell cycle) signaling or autophagy pathways and the induction of specific antiviral signaling pathways that clear the virus infection (Table 2). These individual markers of sensitivity or resistance may together yield predictive profiles. However, further investigations are needed to shed light on the interplay between oncolytic activity on the tumor cells and the immune system. Ultimately, the complexity of these interactions in a background of a heterogeneous tumor and interpatient immune status variations, may require development of personalized ex vivo models to aid in identifying the most promising $\mathrm{OV}$ for a specific patient. The convergence of these developments toward applicable tools will enable classification of each GBM patient as sensitive or resistant to specific OVs. Ideally, future clinical trial design will incorporate more than one OV in parallel arms, such that patients can be stratified to the OV that best matches their tumor properties and/or immune status (Figure 2). Such a selection and stratification approach is expected to significantly improve response rates in OV trials for GBM patients. 
Table 2. Potential predictive markers for sensitivity or resistance to OVs.

\begin{tabular}{|c|c|c|c|}
\hline $\mathrm{OV}$ & Potential Predictive Marker & Effect & Tumor Type/ Cell Line \\
\hline T-VEC & STING & Resistance & Melanoma cell lines [104] \\
\hline \multirow{2}{*}{$\begin{array}{l}\text { Adenovirus } \\
(\text { Ad5 } / 3-\Delta 24)\end{array}$} & $\mathrm{MxA}$ & Resistance & Ovarian carcinoma cell line [110] \\
\hline & High HMGB1 & Resistance & $\begin{array}{l}\text { Patients with advanced metastatic } \\
\text { solid tumors [112] }\end{array}$ \\
\hline$(\Delta 24-R G D)$ & Cyclin D1 & Sensitivity & Pancreatic cell line [113] \\
\hline \multirow{2}{*}{ Vocimagene amiretrorepvec } & $\begin{array}{l}\text { IDH1, PI3K3CA, EGFR, SYNE1 } \\
\text { Neo-epitopes }\end{array}$ & Sensitivity & $\begin{array}{c}\text { Patients with recurrent } \\
\text { high-grade gliomas [118] }\end{array}$ \\
\hline & $\begin{array}{l}\text { NK cells and M0 macrophage } \\
\text { tumor infiltration }\end{array}$ & Resistance & $\begin{array}{c}\text { Patients with recurrent } \\
\text { high-grade gliomas [118] }\end{array}$ \\
\hline \multirow{3}{*}{ MV } & IFITM1 & Resistance & $\begin{array}{l}\text { Transformed mesenchymal } \\
\text { stromal cells [124] }\end{array}$ \\
\hline & RIG-I & Resistance & Sarcoma cells [125] \\
\hline & ISG15 & Resistance & Primary GBM cells [123] \\
\hline \multirow{3}{*}{ NDV } & Bcl-xl & Sensitivity & A549 cell line [128] \\
\hline & Rac-1 & Sensitivity & HaCaT A5-RT3 [132] \\
\hline & STAT3 & Sensitivity & Melanoma cell lines [129] \\
\hline \multirow{4}{*}{ Reovirus (R124) } & JAM-A & Sensitivity & Primary GBM cells [56] \\
\hline & Cathepsin B & Sensitivity & Glioma cell line [144] \\
\hline & P53 and EGFR mutations & Sensitivity & $\begin{array}{l}\text { Patients with non-small cell } \\
\text { lung cancer [145] }\end{array}$ \\
\hline & Ki-67 & Sensitivity & $\begin{array}{l}\text { Patients with high grade gliomas } \\
\text { and metastatic brain tumors [136] }\end{array}$ \\
\hline Oncolytic parvovirus $\mathrm{H}-1$ & Cathepsin B & Sensitivity & Glioma cell line $[18,151]$ \\
\hline \multirow{3}{*}{ Vaccinia virus } & Expression of ILT2 on T cells & Resistance & Melanoma patients [155] \\
\hline & LEF1, STAMBPL1, and SLFN11 & Sensitivity & $\begin{array}{l}\text { myeloid and lymphoid leukemia } \\
\text { cell lines [156] }\end{array}$ \\
\hline & $\begin{array}{l}\text { PVRIG, LPP, CECR1, Arhgef6, IRX3, } \\
\text { IGFBP2, and CD1d }\end{array}$ & Resistance & $\begin{array}{c}\text { myeloid and lymphoid leukemia } \\
\text { cell lines [156] }\end{array}$ \\
\hline
\end{tabular}

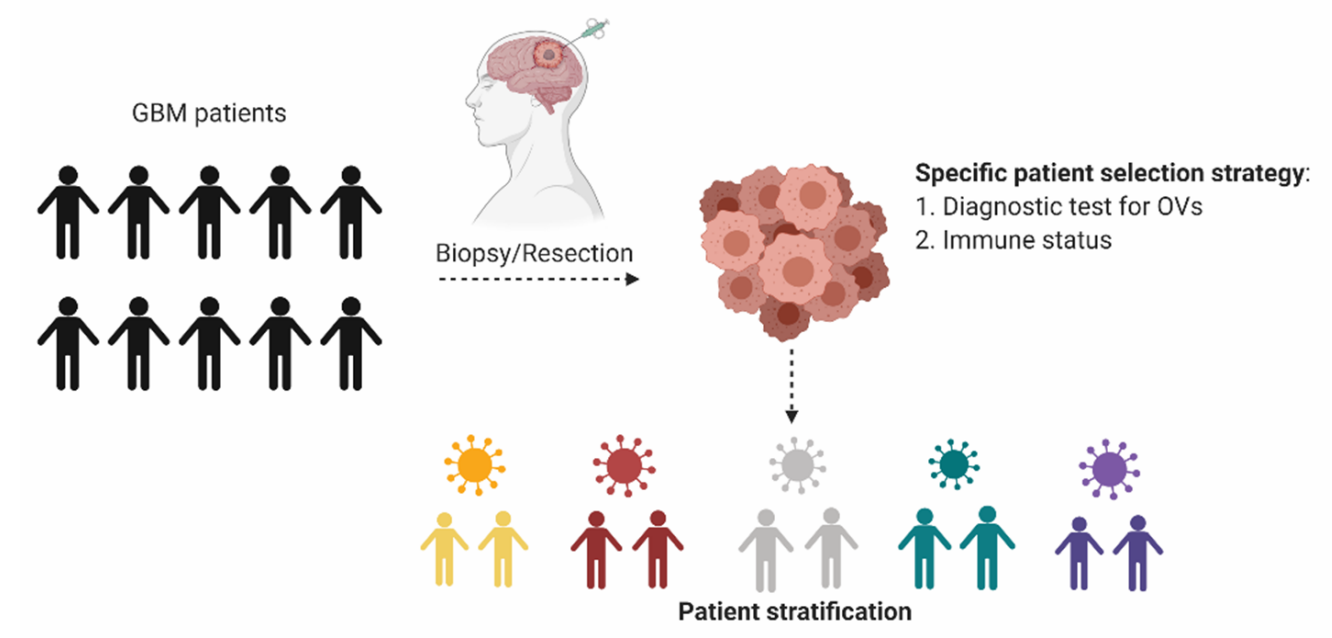

Figure 2. Personalized oncolytic virotherapy. In an envisioned personalized OV trial, resected tumor material from each patient would be used for diagnostic tests to identify the most potent $\mathrm{OV}$, in terms of oncolysis for the particular tumor. Additional tests to determine local and/or systemic immune status after OV infection could further aid in stratifying the patients based on their unique tumor microenvironment and immune status. Created with BioRender.com. 
Funding: The authors gratefully acknowledge the support from Foundation Overleven met Alvleesklierkanker and Foundation Support Casper.

Conflicts of Interest: No conflict of interest to disclose.

\section{References}

1. Zhang, S.; Rabkin, S.D. The discovery and development of oncolytic viruses: Are they the future of cancer immunotherapy? Expert Opin. Drug Discov. 2020. [CrossRef]

2. Harrington, K.; Freeman, D.J.; Kelly, B.; Harper, J.; Soria, J.C. Optimizing oncolytic virotherapy in cancer treatment. Nat. Rev. Drug Discov. 2019, 18, 689-706. [CrossRef] [PubMed]

3. Kaufman, H.L.; Kohlhapp, F.J.; Zloza, A. Oncolytic viruses: A new class of immunotherapy drugs. Nat. Rev. Drug Discov. 2015, 14, 642-662. [CrossRef] [PubMed]

4. Taylor, O.G.; Brzozowski, J.S.; Skelding, K.A. Glioblastoma multiforme: An overview of emerging therapeutic targets. Front. Oncol. 2019, 9, 963. [CrossRef]

5. Stupp, R.; Mason, W.P.; van den Bent, M.J.; Weller, M.; Fisher, B.; Taphoorn, M.J.; Belanger, K.; Brandes, A.A.; Marosi, C.; Bogdahn, U.; et al. Radiotherapy plus concomitant and adjuvant temozolomide for glioblastoma. N. Engl. J. Med. 2005. [CrossRef]

6. De Witt Hamer, P.C.; Ho, V.K.Y.; Zwinderman, A.H.; Zwinderman, A.H.; Ackermans, L.; Ardon, H.; Boomstra, S.; Bouwknegt, W.; van den Brink, W.A.; Dirven, C.M.; et al. Between-hospital variation in mortality and survival after glioblastoma surgery in the Dutch Quality Registry for Neuro Surgery. J. Neurooncol. 2019, 144, 313-323. [CrossRef] [PubMed]

7. Papanastassiou, V.; Rampling, R.; Fraser, M.; Petty, R.; Hadley, D.; Nicoll, J.; Harland, J.; Mabbs, R.; Brown, M. The potential for efficacy of the modified (ICP 34.5) herpes simplex virus HSV1716 following intratumoural injection into human malignant glioma: A proof of principle study. Gene Ther. 2002, 9, 398-406. [CrossRef] [PubMed]

8. Markert, J.M.; Liechty, P.G.; Wang, W.; Gaston, S.; Braz, E.; Karrasch, M.; Nabors, L.B.; Markiewicz, M.; Lakeman, A.D.; Palmer, C.A.; et al. Phase $\mathrm{Ib}$ trial of mutant herpes simplex virus G207 inoculated pre-and post-tumor resection for recurrent GBM. Mol. Ther. 2009, 17, 199-207. [CrossRef] [PubMed]

9. Ning, J.; Wakimoto, H. Oncolytic herpes simplex virus-based strategies: Toward a breakthrough in glioblastoma therapy. Front. Microbiol. 2014, 5, 303. [CrossRef]

10. Kambara, H.; Okano, H.; Chiocca, E.A.; Saeki, Y. An Oncolytic HSV-1 Mutant Expressing ICP34. 5 under Control of a Nestin Promoter Increases Survival of Animals even when Symptomatic from a Brain Tumor. Cancer Res. 2005, 67, 8980-8984.

11. Cheng, P.H.; Wechman, S.L.; McMasters, K.M.; Zhou, H.S. Oncolytic replication of E1b-deleted adenoviruses. Viruses 2015, 7 , 5767-5779. [CrossRef] [PubMed]

12. Suzuki, K.; Fueyo, J.; Krasnykh, V.; Reynolds, P.N.; Curiel, D.T.; Alemany, R. A conditionally replicative adenovirus with enhanced infectivity shows improved oncolytic potency. Clin. Cancer Res. 2001, 7, 120-126. [PubMed]

13. Allen, C.; Opyrchal, M.; Aderca, I.; Schroeder, M.A.; Sarkaria, J.N.; Domingo, E.; Federspiel, M.J.; Galanis, E. Oncolytic measles virus strains have significant antitumor activity against glioma stem cells. Gene Ther. 2013, 20, 444-449. [CrossRef] [PubMed]

14. Schirrmacher, V.; van Gool, S.; Stuecker, W. Breaking therapy resistance: An update on oncolytic newcastle disease virus for improvements of cancer therapy. Biomedicines 2019, 7, 66. [CrossRef] [PubMed]

15. Gong, J.; Mita, M.M. Activated Ras signaling pathways and reovirus oncolysis: An update on the mechanism of preferential reovirus replication in cancer cells. Front. Oncol. 2014, 4, 167. [CrossRef]

16. Gromeier, M.; Lachmann, S.; Rosenfeld, M.R.; Gutin, P.H.; Wimmer, E. Intergeneric poliovirus recombinants for the treatment of malignant glioma. Proc. Natl. Acad. Sci. USA. 2000. [CrossRef] [PubMed]

17. Dobrikova, E.Y.; Broadt, T.; Poiley-Nelson, J.; Yang, X.; Soman, G.; Giardina, S.; Harris, R.; Gromeier, M. Recombinant oncolytic poliovirus eliminates glioma in vivo without genetic adaptation to a pathogenic phenotype. Mol. Ther. 2008. [CrossRef]

18. Nüesch, J.P.F.; Lacroix, J.; Marchini, A.; Rommelaere, J. Molecular pathways: Rodent parvoviruses-Mechanisms of oncolysis and prospects for clinical cancer treatment. Clin. Cancer Res. 2012, 18, 3516-3523. [CrossRef]

19. Chiocca, E.A.; Nassiri, F.; Wang, J.; Peruzzi, P.; Zadeh, G. Viral and other therapies for recurrent glioblastoma: Is a 24-month durable response unusual? Neuro-Oncology 2019, 21, 14-25. [CrossRef]

20. Lang, F.F.; Conrad, C.; Gomez-Manzano, C.; Alfred Yung, W.K.; Sawaya, R.; Weinberg, J.S.; Prabhu, S.S.; Rao, G.; Fuller, G.N.; Aldape, K.D.; et al. Phase I study of DNX-2401 (delta-24-RGD) oncolytic adenovirus: Replication and immunotherapeutic effects in recurrent malignant glioma. J. Clin. Oncol. 2018, 36, 1419-1427. [CrossRef]

21. Cloughesy, T.F.; Landolfi, J.; Vogelbaum, M.A.; Ostertag, D.; Elder, J.B.; Bloomfield, S.; Carter, B.; Chen, C.C.; Kalkanis, S.N.; Kesari, S.; et al. Durable complete responses in some recurrent high-grade glioma patients treated with Toca $511+$ Toca FC. Neuro-Oncology 2018, 20, 1383-1392. [CrossRef]

22. Senzer, N.N.; Kaufman, H.L.; Amatruda, T.; Nemunaitis, M.; Reid, T.; Daniels, G.; Gonzalez, R.; Glaspy, J.; Whitman, E.; Harrington, K.; et al. Phase II Clinical Trial of a Granulocyte-Macrophage Colony-Stimulating Factor-Encoding, SecondGeneration Oncolytic Herpesvirus in Patients With Unresectable Metastatic Melanoma. J. Clin. Oncol. 2009, 27, 5763-5767. [CrossRef] [PubMed]

23. Crespo, I.; Vital, A.L.; Gonzalez-Tablas, M.; Patino, M.D.C.; Otero, A.; Lopes, M.C.; De Oliveira, C.; Domingues, P.; Orfao, A.; Tabernero, M.D. Molecular and Genomic Alterations in Glioblastoma Multiforme. Am. J. Pathol. 2015, 185, 1820-1833. [CrossRef] [PubMed] 
24. Wang, Q.; Hu, X.; Muller, F.; Kim, H.; Squatrito, M.; Mikkelsen, T.; Scarpace, L.; Barthel, F.; Lin, Y.-H.; Satani, N.; et al. Tumor Evolution of Glioma Intrinsic Gene Expression Subtype Associates With Immunological Changes in the Microenvironment. Neuro-Oncology 2016, 18, vi202. [CrossRef]

25. Gill, B.J.; Pisapia, D.J.; Malone, H.R.; Goldstein, H.; Lei, L.; Sonabend, A.; Yun, J.; Samanamud, J.; Sims, J.S.; Banu, M.; et al. MRI-localized biopsies reveal subtype-specific differences in molecular and cellular composition at the margins of glioblastoma. Proc. Natl. Acad. Sci. USA 2014, 111, 12550-12555. [CrossRef]

26. Verhaak, R.G.; Hoadley, K.A.; Purdom, E.; Wang, V.; Qi, Y.; Wilkerson, M.D.; Miller, C.R.; Ding, L.; Golub, T.; Mesirov, J.P.; et al. Integrated Genomic Analysis Identifies Clinically Relevant Subtypes of Glioblastoma Characterized by Abnormalities in PDGFRA, IDH1, EGFR, and NF1. Cancer Cell. 2010, 17, 98-110. [CrossRef] [PubMed]

27. Doucette, T.; Rao, G.; Rao, A.; Shen, L.; Aldape, K.; Wei, J.; Dziurzynski, K.; Gilbert, M.; Heimberger, A.B. Immune heterogeneity of glioblastoma subtypes: Extrapolation from the cancer genome atlas. Cancer Immunol. Res. 2013. [CrossRef]

28. Weller, M.; Cloughesy, T.; Perry, J.R.; Wick, W. Standards of care for treatment of recurrent glioblastoma-are we there yet? Neuro-Oncology 2013, 15, 4-27. [CrossRef]

29. Weller, M.; van den Bent, M.; Preusser, M.; Le Rhun, E.; Tonn, J.C.; Minniti, G.; Bendszus, M.; Balana, C.; Chinot, O.; Dirven, L.; et al. EANO guidelines on the diagnosis and treatment of diffuse gliomas of adulthood. Nat. Rev. Clin. Oncol. 2020. [CrossRef] [PubMed]

30. Patel, A.P.; Tirosh, I.; Trombetta, J.J.; Shalek, A.K.; Gillespie, S.M.; Wakimoto, H.; Cahill, D.P.; Nahed, B.V.; Curry, W.T.; Martuza, R.L.; et al. Single-cell RNA-seq highlights intratumoral heterogeneity in primary glioblastoma. Science 2014, 344, 1396-1402. [CrossRef]

31. Sottoriva, A.; Spiteri, I.; Piccirillo, S.G.M.; Touloumis, A.; Collins, V.P.; Marioni, J.C.; Curtis, C.; Watts, C.; Tavaré, S. Intratumor heterogeneity in human glioblastoma reflects cancer evolutionary dynamics. Proc. Natl. Acad. Sci. USA 2013, 110, 4009-4014. [CrossRef]

32. Schäfer, N.; Gielen, G.H.; Rauschenbach, L.; Kebir, S.; Till, A.; Reinartz, R.; Simon, M.; Niehusmann, P.; Kleinschnitz, C.; Herrlinger, U.; et al. Longitudinal heterogeneity in glioblastoma: Moving targets in recurrent versus primary tumors. J. Transl. Med. 2019, 17, 1-9. [CrossRef]

33. Lee, A.; Arasaratnam, M.; Chan, D.L.H.; Khasraw, M.; Howell, V.M.; Wheeler, H. Anti-epidermal growth factor receptor therapy for glioblastoma in adults. Cochrane Database Syst. Rev. 2020. [CrossRef]

34. Cheng, L.; Huang, Z.; Zhou, W.; Wu, Q.; Donnola, S.; James, K.; Fang, X.; Sloan, A.E.; Mao, Y.; Lathia, J.D.; et al. Glioblastoma Stem Cells Generate Vascular Pericytes to Support Vessel Function and Tumor Growth. Cell 2013, 153, 139-152. [CrossRef]

35. Darmanis, S.; Sloan, S.A.; Croote, D.; Mignardi, M.; Chernikova, S.; Samghababi, P.; Zhang, Y.; Neff, N.; Kowarsky, M.; Caneda, C.; et al. Single-Cell RNA-Seq Analysis of Infiltrating Neoplastic Cells at the Migrating Front. of Human Glioblastoma. Cell Rep. 2017, 21, 1399-1410. [CrossRef] [PubMed]

36. Alcantara Llaguno, S.R.; Parada, L.F. Cell of origin of glioma: Biological and clinical implications. Br. J. Cancer 2016. [CrossRef] [PubMed]

37. Engelhardt, B.; Carare, R.O.; Bechmann, I.; Flügel, A.; Laman, J.D.; Weller, R.O. Vascular, glial, and lymphatic immune gateways of the central nervous system. Acta Neuropathol. 2016. [CrossRef] [PubMed]

38. Ransohoff, R.M.; Engelhardt, B. The anatomical and cellular basis of immune surveillance in the central nervous system. Nat. Publ. Gr. 2012, 12. [CrossRef] [PubMed]

39. Ludewig, P.; Gallizioli, M.; Urra, X.; Behr, S.; Brait, V.H.; Gelderblom, M.; Magnus, T.; Planas, A.M. Biochimica et Biophysica Acta Dendritic cells in brain diseases. BBA Mol. Basis Dis. 2016, 1862, 352-367. [CrossRef]

40. Miller, S.D.; Mahon, E.J.M.C.; Schreiner, B.; Bailey, S.L. Antigen Presentation in the CNS by Myeloid Dendritic Cells Drives Progression of Relapsing Experimental Autoimmune Encephalomyelitis. Ann. N. Y. Acad. Sci. 2007, 191, 179-191. [CrossRef]

41. Louveau, A.; Smirnov, I.; Keyes, T.J.; Eccles, J.D.; Rouhani , S.J.; Peske, J.D.; Derecki, N.C.; Castle, D.; Mandell, J.W.; Lee, K.S.; et al. Structural and functional features of central nervous system lymphatic vessels. Nature 2015, 523, 337-341. [CrossRef] [PubMed]

42. Sevenich, L. Brain-Resident Microglia and Blood-Borne Macrophages Orchestrate Central Nervous System inflammation in Neurodegenerative Disorders and Brain Cancer. Front. Immunol. 2018, 9, 697. [CrossRef] [PubMed]

43. Hambardzumyan, D.; Gutmann, D.H.; Kettenmann, H. The role of microglia and macrophages in glioma maintenance and progression. Nat. Neurosci. 2016, 19, 20-27. [CrossRef]

44. Takenaka, M.C.; Gabriely, G.; Rothhammer, V.; Mascanfroni, I.D.; Wheeler, M.A.; Chao, C.; Gutiérrez-vázquez, C.; Kenison, J.; Tjon, E.C.; Barroso, A.; et al. Control of tumor-associated macrophages and T cells in glioblastoma via AHR and CD39. Nat. Neurosci. 2019, 22, 729-740. [CrossRef]

45. Zhou, W.; Ke, S.Q.; Huang, Z.; Flavahan, W.; Fang, X.; Paul, J.; Wu, L.; Sloan, A.E.; Mclendon, R.E.; Li, X.; et al. Periostin secreted by glioblastoma stem cells recruits M2 tumour-associated macrophages and promotes malignant growth. Nat. Cell Biol. 2015, 17, 170-182. [CrossRef] [PubMed]

46. Mantovani, A.; Marchesi, F.; Malesci, A.; Laghi, L.; Allavena, P. Tumour-associated macrophages as treatment targets in oncology. Nat. Rev. Clin. Oncol. 2017, 14, 399-416. [CrossRef] [PubMed]

47. Shi, Y.; Ping, Y.; Zhou, W.; He, Z.; Chen, C.; Bian, B.; Zhang, L.; Chen, L.; Lan, X.; Zhang, X.; et al. Tumour-associated macrophages secrete pleiotrophin to promote PTPRZ1 signalling in glioblastoma stem cells for tumour growth. Nat. Commun. 2017, 8, 1-17. [CrossRef] 
48. Sørensen, M.D. Tumour-associated microglia/macrophages predict poor prognosis in high-grade gliomas and correlate with an aggressive tumour subtype. Neuropathol. Appl. Neurobiol. 2018, 44, 185-206. [CrossRef] [PubMed]

49. Lu-emerson, C.; Snuderl, M.; Kirkpatrick, N.D.; Goveia, J.; Davidson, C.; Huang, Y.; Riedemann, L.; Taylor, J.; Ivy, P.; Duda, G.; et al. Increase in tumor-associated macrophages after antiangiogenic therapy is associated with poor survival among patients with recurrent glioblastoma. Neuro-Oncology 2013, 15, 1079-1087. [CrossRef]

50. Woroniecka, K.; Chongsathidkiet, P.; Rhodin, K.; Kemeny, H.; Dechant, C.; Farber, S.H.; Elsamadicy, A.A.; Cui, X.; Koyama, S.; Jackson, C.; et al. T-Cell Exhaustion Signatures Vary with Tumor Type and Are Severe in Glioblastoma. Clin. Cancer Res. 2018, 44, 4175-4187. [CrossRef] [PubMed]

51. Heimberger, A.B.; Abou-ghazal, M.; Reina-ortiz, C.; Yang, D.S.; Sun, W.; Qiao, W.; Hiraoka, N.; Fuller, G.N. Incidence and Prognostic Impact of FoxP3 + Regulatory T Cells in Human Gliomas. Clin. Cancer Res. 2008, 14, 5166-5173. [CrossRef] [PubMed]

52. Martinez-lage, M.; Lynch, T.M.; Bi, Y.; Cocito, C.; Way, G.P.; Pal, S.; Haller, J.; Yan, R.E.; Ziober, A.; Nguyen, A.; et al. Immune landscapes associated with different glioblastoma molecular subtypes. Acta Neuropathol. Commun. 2019, 6, 1-12. [CrossRef]

53. Büttner, R.; Longshore, J.W.; López-Ríos, F.; Vandergrift, W.A., III.; Patel, S.J.; Cachia, D.; Bartee, E. Implementing TMB measurement in clinical practice: Considerations on assay requirements. ESMO Open 2019, 4, e00044. [CrossRef]

54. Alexandrov, L.B.; Nik-Zainal, S.; Wedge, D.C.; Aparicio, S.A.; Behjati, S.; Biankin, A.V.; Bignell, G.R.; Bolli, N.; Borg, A.; Børresen-Dale, A.L.; et al. Signatures of mutational processes in human cancer. Nature 2013, 500, 415-421. [CrossRef]

55. Lamfers, M.L.M.; Idema, S.; Bosscher, L.; Heukelom, S.; Moeniralm, S.; Van Der Meulen-Muileman, I.H.; Overmeer, R.M.; Van Der Valk, P.; Van Beusechem, V.W.; Gerritsen, W.R. Differential effects of combined Ad5- $\Delta 24 R G D$ and radiation therapy in in vitro versus in vivo models of malignant glioma. Clin. Cancer Res. 2007, 13, 7451-7458. [CrossRef] [PubMed]

56. Van Den Hengel, S.K.; Balvers, R.K.; Dautzenberg, I.J.C.; Van Den Wollenberg, D.J.M.; Kloezeman, J.J.; Lamfers, M.L.; Sillivis-Smit, P.A.E.; Hoeben, R.C. Heterogeneous reovirus susceptibility in human glioblastoma stem-like cell cultures. Cancer Gene Ther. 2013, 20, 507-513. [CrossRef] [PubMed]

57. Grill, J.; Van Beusechem, V.W.; Van Der Valk, P.; Dirven, C.M.F.; Leonhart, A.; Pherai, D.S.; Haisma, H.J.; Pinedo, H.M.; Curiel, D.T.; Gerritsen, W.R. Combined Targeting of Adenoviruses to Integrins and Epidermal Growth Factor Receptors Increases Gene Transfer into Primary Glioma Cells and Spheroids. Clin. Cancer Res. 2001, 7, 641-650.

58. Sonabend, A.M.; Ulasov, I.V.; Han, Y.; Lesniak, M.S. Oncolytic adenoviral therapy for glioblastoma multiforme. Neurosurg. Focus 2006, 20, E19. [CrossRef]

59. Balvers, R.K.; Gomez-Manzano, C.; Jiang, H.; Piya, S.; Klein, S.R.; Lamfers, M.L.M.; Dirven, C.M.F.; Fueyo, J. Advances in Oncolytic Virotherapy for Brain Tumors; Elsevier Inc.: Amsterdam, The Netherlands, 2013. [CrossRef]

60. Oh, E.; Hong, J.; Kwon, O.J.; Yun, C.O. A hypoxia- and telomerase-responsive oncolytic adenovirus expressing secretable trimeric TRAIL triggers tumour-specific apoptosis and promotes viral dispersion in TRAIL-resistant glioblastoma. Sci. Rep. 2018, 8, 1-13. [CrossRef] [PubMed]

61. Post, D.E.; Sandberg, E.M.; Kyle, M.M.; Devi, N.S.; Brat, D.J.; Xu, Z.; Tighiouart, M.; Van Meir, E.G. Targeted cancer gene therapy using a hypoxia inducible factor-dependent oncolytic adenovirus armed with interleukin-4. Cancer Res. 2007, 67, 6872-6881. [CrossRef]

62. Ulasov, I.V.; Rivera, A.A.; Sonabend, A.M.; Rivera, L.B.; Wang, M.; Zhu, Z.B.; Lesniak, M.S. Comparative evaluation of survivin, midkine and CXCR4 promoters for transcriptional targeting of glioma gene therapy. Cancer Biol. Ther. 2007. [CrossRef] [PubMed]

63. Hoffmann, D.; Wildner, O. Efficient generation of double heterologous promoter controlled oncolytic adenovirus vectors by a single homologous recombination step in Escherichia coli. BMC Biotechnol. 2006. [CrossRef] [PubMed]

64. Saito, N.; Hirai, N.; Aoki, K.; Sato, S.; Suzuki, R.; Hiramoto, Y.; Fujita, S.; Nakayama, H.; Hayashi, M.; Sakurai, T.; et al. Genetic and lineage classification of glioma-initiating cells identifies a clinically relevant glioblastoma model. Cancers 2019, 11, 1564. [CrossRef] [PubMed]

65. Hardison, S.E.; Brown, G.D. C-type Lectin Receptors Orchestrate Anti-Fungal Immunity. Nat. Immunol. 2012, 13, 817-822. [CrossRef] [PubMed]

66. Goubau, D.; Deddouche, S.; Reis e Sousa, C. Cytosolic Sensing of Viruses. Immunity 2013, 38, 855-869. [CrossRef] [PubMed]

67. Lee, H.C.; Chathuranga, K.; Lee, J.S. Intracellular sensing of viral genomes and viral evasion. Exp. Mol. Med. 2019, 51. [CrossRef]

68. Caneparo, V.; Landolfo, S.; Gariglio, M.; De Andrea, M. The absent in melanoma 2-like receptor IFN-inducible protein 16 as an inflammasome regulator in systemic lupus erythematosus: The dark side of sensing microbes. Front. Immunol. 2018, 9, 1-14. [CrossRef]

69. Lazear, H.M.; Nice, T.J.; Diamond, M.S. Interferon- $\lambda$ : Immune Functions at Barrier Surfaces and Beyond. Immunity 2015, 43, 15-28. [CrossRef] [PubMed]

70. Levy, D.E.; Marié, I.J.; Durbin, J.E. Induction and function of type I and III interferon in response to viral infection. Curr. Opin. Virol. 2012, 1, 476-486. [CrossRef] [PubMed]

71. Hornung, V.; Hartmann, R.; Ablasser, A.; Hopfner, K.P. OAS proteins and cGAS: Unifying concepts in sensing and responding to cytosolic nucleic acids. Nat. Rev. Immunol. 2014, 14, 521-528. [CrossRef]

72. Unterholzner, L.; Keating, S.E.; Baran, M.; Horan, K.A.; Jensen, S.B.; Sharma, S.; Sirois, C.M.; Jin, T.; Latz, E.; Xiao, T.S.; et al. IFI16 is an innate immune sensor for intracellular DNA. Nat. Immunol. 2010, 11, 997-1004. [CrossRef] [PubMed]

73. Lazear, H.M.; Schoggins, J.W.; Diamond, M.S.; Hill, C.; Andrew, M.; Programs, I.; Louis, S. Shared and Distinct Functions of Type I and Type III Interferons. Immunity 2019, 50, 907-923. [CrossRef] [PubMed] 
74. Lionel BIvashkivand Laura, T. Donlin1 Regulation of type I interferon responses Lionel. Bone 2008, 23, 1-7. [CrossRef]

75. Ma, F.; Li, B.; Liu, S.; Iyer, S.S.; Yu, Y.; Wu, A.; Cheng, G. Positive Feedback Regulation of Type I IFN Production by the IFN-Inducible DNA Sensor cGAS. J. Immunol. 2015, 194, 1545-1554. [CrossRef]

76. Sadler, A.J.; Williams, B.R.G. Interferon-inducible antiviral effectors. Nat. Rev. Immunol. 2008, 8, 559-568. [CrossRef]

77. Froechlich, G.; Caiazza, C.; Gentile, C.; D’alise, A.M.; De Lucia, M.; Langone, F.; Leoni, G.; Cotugno, G.; Scisciola, V.; Nicosia, A.; et al. Integrity of the antiviral STING-mediated DNA sensing in tumor cells is required to sustain the immunotherapeutic efficacy of herpes simplex oncolytic virus. Cancers 2020, 12, 3407. [CrossRef]

78. Barber, G.N. STING: Infection, inflammation and cancer. Nature 2015, 15, 11-13. [CrossRef] [PubMed]

79. Wang, Y.; Jiang, K.; Zhang, Q.; Meng, S.; Ding, C. Autophagy in negative-strand RNA virus infection. Front. Microbiol. 2018, 9 , 206. [CrossRef] [PubMed]

80. Dikic, I.; Elazar, Z. Mechanism and medical implications of mammalian autophagy. Nat. Rev. Mol. Cell Biol. 2018, 19, 349-364. [CrossRef] [PubMed]

81. Mizushima, N.; Yoshimori, T.; Ohsumi, Y. The Role of Atg Proteins in Autophagosome Formation. Annu. Rev. Cell Dev. Biol. 2011, 27, 107-132. [CrossRef] [PubMed]

82. Sharma, V.; Verma, S.; Seranova, E.; Sarkar, S.; Kumar, D. Selective autophagy and xenophagy in infection and disease. Front. Cell Dev. Biol. 2018, 6, 47. [CrossRef]

83. Choi, Y.; Bowman, J.W.; Jung, J.U. Autophagy during viral infection-A double-edged sword. Nat. Rev. Microbiol. 2018, 16, 341-354. [CrossRef]

84. Lee, H.K.; Lund, J.M.; Ramanathan, B.; Mizushima, N.; Iwasaki, A. Autophagy-dependent viral recognition by plasmacytoid dendritic cells. Science 2007, 315, 1398-1401. [CrossRef] [PubMed]

85. Orvedahl, A.; MacPherson, S.; Sumpter, R.; Tallóczy, Z.; Zou, Z.; Levine, B. Autophagy Protects against Sindbis Virus Infection of the Central Nervous System. Cell Host Microbe 2010, 7, 115-127. [CrossRef] [PubMed]

86. Moy, R.H.; Gold, B.; Molleston, J.M.; Schad, V.; Yanger, K.; Salzano, M.V.; Yagi, Y.; Fitzgerald, K.A.; Stanger, B.Z.; Soldan, S.S.; et al. Antiviral autophagy restricts rift valley fever virus infection and is conserved from flies to mammals. Immunity 2014, 40, 51-65. [CrossRef] [PubMed]

87. Lussignol, M.; Esclatine, A. Herpesvirus and autophagy: “All right, everybody be cool, this is a robbery!”. Viruses 2017, 9, 372. [CrossRef] [PubMed]

88. Heaton, N.S.; Randall, G. Dengue virus-induced autophagy regulates lipid metabolism. Cell Host Microbe. $2010,8,422-432$. [CrossRef] [PubMed]

89. Cheng, P.H.; Lian, S.; Zhao, R.; Rao, X.M.; McMasters, K.M.; Zhou, H.S. Combination of autophagy inducer rapamycin and oncolytic adenovirus improves antitumor effect in cancer cells. Virol. J. 2013, 10, 293. [CrossRef] [PubMed]

90. Comins, C.; Simpson, G.R.; Rogers, W.; Relph, K.; Harrington, K.; Melcher, A.; Roulstone, V.; Kyula, J.; Pandha, H. Synergistic antitumour effects of rapamycin and oncolytic reovirus. Cancer Gene Ther. 2018, 25, 148-160. [CrossRef]

91. Fu, X.; Tao, L.; Rivera, A.; Zhang, X. Rapamycin enhances the activity of oncolytic herpes simplex virus against tumor cells that are resistant to virus replication. Int. J. Cancer 2011, 129, 1503-1510. [CrossRef] [PubMed]

92. Stanford, M.M.; Barrett, J.W.; Nazarian, S.H.; Werden, S.; McFadden, G. Oncolytic Virotherapy Synergism with Signaling Inhibitors: Rapamycin Increases Myxoma Virus Tropism for Human Tumor Cells. J. Virol. 2007, 81, 1251-1260. [CrossRef] [PubMed]

93. Goetz, C.; Dobrikova, E.; Shveygert, M.; Dobrikov, M.; Gromeier, M. Oncolytic poliovirus against malignant glioma. Future Virol. 2011, 6, 1045-1058. [CrossRef] [PubMed]

94. Hu, L.; Jiang, K.; Ding, C.; Meng, S. Targeting autophagy for oncolytic immunotherapy. Biomedicines 2017, 5, 1-9. [CrossRef] [PubMed]

95. Jiang, H.; White, E.J.; Rios-Vicil, C.I.; Xu, J.; Gomez-Manzano, C.; Fueyo, J. Human Adenovirus Type 5 Induces Cell Lysis through Autophagy and Autophagy-Triggered Caspase Activity. J. Virol. 2011, 85, 4720-4729. [CrossRef] [PubMed]

96. Alonso, M.M.; Jiang, H.; Yokoyama, T.; Xu, J.; Bekele, N.B.; Lang, F.F.; Kondo, S.; Gomez-Manzano, C.; Fueyo, J. Delta-24-RGD in combination with RAD001 induces enhanced anti-glioma effect via autophagic cell death. Mol. Ther. 2008, 16, 487-493. [CrossRef] [PubMed]

97. Tazawa, H.; Kagawa, S.; Fujiwara, T. Oncolytic adenovirus-induced autophagy: Tumor-suppressive efect and molecular basis. Acta Med. Okayama 2013, 67, 333-342. [CrossRef] [PubMed]

98. Tazawa, H.; Kuroda, S.; Hasei, J.; Kagawa, S.; Fujiwara, T. Impact of autophagy in oncolytic adenoviral therapy for cancer. Int. J. Mol. Sci. 2017, 18, 1479. [CrossRef]

99. Ma, W.; He, H.; Wang, H. Oncolytic herpes simplex virus and immunotherapy. BMC Immunol. 2018, 19, 1-11. [CrossRef]

100. Totsch, S.K.; Schlappi, C.; Kang, K.D.; Ishizuka, A.S.; Lynn, G.M.; Fox, B.; Beierle, E.A.; Whitley, R.J.; Markert, J.M.; Gillespie, G.Y.; et al. Oncolytic herpes simplex virus immunotherapy for brain tumors: Current pitfalls and emerging strategies to overcome therapeutic resistance. Oncogene 2019, 38, 6159-6171. [CrossRef]

101. Peters, C.; Paget, M.; Tshilenge, K.T.; Saha, D.; Antoszczyk, S.; Baars, A.; Frost, T.; Martuza, R.L.; Wakimoto, H.; Rabkin, S.D. Restriction of Replication of Oncolytic Herpes Simplex Virus with a Deletion of $\gamma 34.5$ in Glioblastoma Stem-Like Cells. J. Virol. 2018. [CrossRef] 
102. Lalu, M.; Leung, G.J.; Dong, Y.Y.; Montroy, J.; Butler, C.; Auer, R.C.; Fergusson, D.A. Mapping the preclinical to clinical evidence and development trajectory of the oncolytic virus talimogene laherparepvec (T-VEC): A systematic review. BMJ Open 2019, 9, e029475. [CrossRef]

103. Harrington, K.J.; Andtbacka, R.H.I.; Collichio, F.; Downey, G.; Chen, L.; Szabo, Z.; Kaufman, L.K. Efficacy and safety of talimogene laherparepvec versus granulocyte-macrophage colony-stimulating factor in patients with stage IIIB/C and IVM1a melanoma: Subanalysis of the Phase III OPTiM trial. Onco Targets Ther. 2016, 9, 7081-7093. [CrossRef]

104. Bommareddy, P.K.; Zloza, A.; Rabkin, S.D.; Kaufman, H.L. Oncolytic virus immunotherapy induces immunogenic cell death and overcomes STING deficiency in melanoma. Oncoimmunology 2019, 8, e1591875. [CrossRef]

105. Rosewell Shaw, A.; Suzuki, M. Recent advances in oncolytic adenovirus therapies for cancer. Curr. Opin. Virol. 2016, 21, 9-15. [CrossRef] [PubMed]

106. Larson, C.; Oronsky, B.; Scicinski, J.; Fanger, G.R.; Stirn, M.; Oronsky, A.; Reid, T.R. Going viral: A review of replication-selective oncolytic adenoviruses. Oncotarget 2015, 6, 19976-19989. [CrossRef] [PubMed]

107. Chiocca, E.A.; Abbed, K.M.; Tatter, S.; Louis, D.N.; Hochberg, F.H.; Barker, F.; Kracher, J.; Grossman, S.A.; Fisher, J.D.; Carson, K.; et al. A phase I open-label, dose-escalation, multi-institutional trial of injection with an E1B-attenuated adenovirus, ONYX-015, into the peritumoral region of recurrent malignant gliomas, in the adjuvant setting. Mol. Ther. 2004, 10, 958-966. [CrossRef] [PubMed]

108. Bossche WBLVan Den Kleijn, A.; Teunissen, C.E.; Voerman, J.S.A.; Teodosio, C.; David, P.; Dongen, J.J.M.; Van Dirven, C.M.F.; Lamfers, M.L.M. Oncolytic virotherapy in glioblastoma patients induces a tumor macrophage phenotypic shift leading to an altered glioblastoma microenvironment. Neuro-Oncology 2018, 20, 1494-1504. [CrossRef] [PubMed]

109. Liikanen, I.; Monsurrò, V.; Ahtiainen, L.; Raki, M.; Hakkarainen, T.; Diaconu, I.; Escutenaire, S.; Hemminki, O.; Dias, J.D.; Cerullo, V.; et al. Induction of interferon pathways mediates in vivo resistance to oncolytic adenovirus. Mol. Ther. 2011, 19, 1858-1866. [CrossRef] [PubMed]

110. Haller, O.; Kochs, G. Human MxA protein: An interferon-induced dynamin-like GTPase with broad antiviral activity. J. Interf Cytokine Res. 2011, 31, 79-87. [CrossRef]

111. Taipale, K.; Liikanen, I.; Juhila, J.; Turkki, R.; Tähtinen, S.; Kankainen, M.; Vassilev, L.; Ristimäki, A.; Koski, A.; Kanerva, A.; et al. Chronic activation of innate immunity correlates with poor prognosis in cancer patients treated with oncolytic adenovirus. Mol. Ther. 2016, 24, 175-183. [CrossRef]

112. Liikanen, I.; Koski, A.; Merisalo-Soikkeli, M.; Hemminki, O.; Oksanen, M.; Kairemo, K.; Joensuu, T.; Kanerva, A.; Hemminki, A. Serum HMGB1 is a predictive and prognostic biomarker for Oncolytic immunotherapy. Oncoimmunology 2015, 4, e989771. [CrossRef] [PubMed]

113. Dai, B.; Roife, D.; Kang, Y.; Gumin, J.; Perez, M.V.R.; Li, X.; Pratt, M.; Brekken, R.A.; Fueyo-margareto, J.; Lang, F.F.; et al. Preclinical Evaluation of Sequential Combination of Oncolytic Adenovirus Delta-24-RGD and Phosphatidylserine-Targeting Antibody in Pancreatic Ductal Adenocarcinoma. Mol. Cancer Ther. 2017, 16, 662-671. [CrossRef] [PubMed]

114. Musgrove, E.A.; Caldon, C.E.; Barraclough, J.; Stone, A.; Sutherland, R.L. Cyclin D as a therapeutic target in cancer. Nat. Rev. Cancer 2011, 11. [CrossRef] [PubMed]

115. Logg, C.R.; Robbins, J.M.; Jolly, D.J.; Gruber, H.E.; Kasahara, N. Retroviral Replicating Vectors in Cancer, 1st ed.; Elsevier Inc.: Amsterdam, The Netherlands, 2012; Volume 507. [CrossRef]

116. Perez, O.D.; Logg, C.R.; Hiraoka, K.; Diago, O.; Burnett, R.; Inagaki, A.; Jolson, D.; Amundson, K.; Buckley, T.; Lohse, D.; et al. Design and selection of toca 511 for clinical use: Modified retroviral replicating vector with improved stability and gene expression. Mol. Ther. 2012, 20, 1689-1698. [CrossRef] [PubMed]

117. Cloughesy, T.F.; Petrecca, K.; Walbert, T.; Butowski, N.; Salacz, M.; Perry, J.; Damek, D.; Bota, D.; Bettegowda, C.; Zhu, J.J.; et al. Effect of Vocimagene Amiretrorepvec in Combination with Flucytosine vs Standard of Care on Survival following Tumor Resection in Patients with Recurrent High-Grade Glioma: A Randomized Clinical Trial. JAMA Oncol. 2020, 6, 1939-1946. [CrossRef] [PubMed]

118. Accomando, W.P.; Rao, A.R.; Hogan, D.J.; Newman, A.M.; Nakao, A.; Alizadeh, A.A.; Diehn, M.; Diago, O.R.; Gammon, D.; Haghighi, A.; et al. Molecular and Immunologic Signatures are Related to Clinical Benefit from Treatment with Vocimagene Amiretrorepvec (Toca 511) and 5-Fluorocytosine (Toca FC) in Patients with Glioma. Clin. Cancer Res. 2020, 26, 6176-6186. [CrossRef] [PubMed]

119. Msaouel, P.; Opyrchal, M.; Dispenzieri, A.; Peng, K.W.; Federspiel, M.J.; Russell, S.J.; Galanis, E. Clinical Trials with Oncolytic Measles Virus: Current Status and Future Prospects. Curr. Cancer Drug Targets 2017, 18, 177-187. [CrossRef]

120. Laksono, B.M.; de Vries, R.D.; McQuaid, S.; Duprex, W.P.; de Swart, R.L. Measles virus host invasion and pathogenesis. Viruses 2016, 8, 210. [CrossRef] [PubMed]

121. Lin, L.T.; Richardson, C.D. The host cell receptors for measles virus and their interaction with the viral Hemagglutinin (H) Protein. Viruses. 2016, 8, 250. [CrossRef]

122. Ulasov, I.V.; Tyler, M.A.; Zheng, S.; Han, Y.; Lesniak, M.S. CD46 represents a target for adenoviral gene therapy of malignant glioma. Hum Gene Ther. 2006, 17, 556-564. [CrossRef] [PubMed]

123. Kurokawa, C.; Iankov, I.D.; Anderson, S.K.; Aderca, I.; Leontovich, A.A.; Maurer, M.J.; Oberg, A.L.; Schroeder, M.A.; Giannini, C.; Greiner, S.M.; et al. Constitutive interferon pathway activation in tumors as an efficacy determinant following oncolytic virotherapy. J. Natl. Cancer Inst. 2018, 110, 1123-1132. [CrossRef] [PubMed] 
124. Aref, S.; Castleton, A.Z.; Bailey, K.; Burt, R.; Dey, A.; Leongamornlert, D.; Mitchell, R.J.; Okasha, D.; Fielding, A.K. Type 1 Interferon Responses Underlie Tumor-Selective Replication of Oncolytic Measles Virus. Mol. Ther. 2020, 28, 1-13. [CrossRef] [PubMed]

125. Berchtold, S.; Lampe, J.; Weiland, T.; Smirnow, I.; Schleicher, S.; Handgretinger, R.; Kopp, H.-G.; Reiser, J.; Stubenrauch, F.; Mayer, N.; et al. Innate Immune Defense Defines Susceptibility of Sarcoma Cells to Measles Vaccine Virus-Based Oncolysis. J. Virol. 2013, 87, 3484-3501. [CrossRef] [PubMed]

126. Krishnamurthy, S.; Takimoto, T.; Scroggs, R.A.; Portner, A. Differentially Regulated Interferon Response Determines the Outcome of Newcastle Disease Virus Infection in Normal and Tumor Cell Lines. J. Virol. 2006, 80, 5145-5155. [CrossRef]

127. Zamarin, D.; Martínez-Sobrido, L.; Kelly, K.; Mansour, M.; Sheng, G.; Vigila, A.; García-Sastre, A.; Palese, P.; Fong, Y. Enhancement of oncolytic properties of recombinant newcastle disease virus through antagonism of cellular innate immune responses. Mol. Ther. 2009, 17, 697-706. [CrossRef] [PubMed]

128. Mansour, M.; Palese, P.; Zamarin, D. Oncolytic Specificity of Newcastle Disease Virus Is Mediated by Selectivity for ApoptosisResistant Cells. J. Virol. 2011, 85, 6015-6023. [CrossRef]

129. Shao, X.; Wang, X.; Guo, X.; Jiang, K.; Ye, T.; Chen, J.; Fang, J.; Gu, L.; Wang, S.; Zhang, G.; et al. STAT3 contributes to oncolytic newcastle disease virus-induced immunogenic cell death in melanoma cells. Front. Oncol. 2019, 9, 436. [CrossRef]

130. Meng, C.; Zhou, Z.; Jiang, K.; Yu, S.; Jia, L.; Wu, Y.; Liu, Y.; Meng, S.; Ding, C. Newcastle disease virus triggers autophagy in U251 glioma cells to enhance virus replication. Arch. Virol. 2012, 157, 1011-1018. [CrossRef] [PubMed]

131. Jiang, K.; Li, Y.; Zhu, Q.; Xu, J.; Wang, Y.; Deng, W.; Liu, Q.; Zhang, G.; Meng, S. Pharmacological modulation of autophagy enhances Newcastle disease virus-mediated oncolysis in drug-resistant lung cancer cells. BMC Cancer 2014, 14, 551. [CrossRef] [PubMed]

132. Puhlmann, J.; Puehler, F.; Mumberg, D.; Boukamp, P.; Beier, R. Rac1 is required for oncolytic NDV replication in human cancer cells and establishes a link between tumorigenesis and sensitivity to oncolytic virus. Oncogene 2010, 29, 2205-2216. [CrossRef] [PubMed]

133. Van den Broeke, C.; Jacob, T.; Favoreel, H.W. Rho'ing in and out of cells: Viral interactions with Rho GTPase signaling. Small GTPases 2014, 5, e28318. [CrossRef] [PubMed]

134. Lai, Y.J.; Tsai, J.C.; Tseng, Y.T.; Wu, M.S.; Liu, W.S.; Lam, H.I.; Yu, J.H.; Nozell, S.E.; Benveniste, E.N. Small G protein Rac GTPases regulate the maintenance of glioblastoma stem-like cells in vitro and in vivo. Oncotarget 2017, 8, 18031-18049. [CrossRef]

135. Forsyth, P.; Roldán, G.; George, D.; Wallace, C.; Palmer, C.A.; Morris, D.; Cairncross, G.; Matthews, M.V.; Markert, J.; Gillespie, Y.; et al. A phase I trial of intratumoral administration of reovirus in patients with histologically confirmed recurrent malignant gliomas. Mol. Ther. 2008, 16, 627-632. [CrossRef] [PubMed]

136. Samson, A.; Scott, K.J.; Taggart, D.; West, E.J.; Wilson, E.; Nuovo, G.J.; Thomson, S.; Corns, R.; Mathew, R.K.; Fuller, M.J.; et al. Intravenous delivery of oncolytic reovirus to brain tumor patients immunologically primes for subsequent checkpoint blockade. Sci. Transl. Med. 2018, 10, eaam7577. [CrossRef] [PubMed]

137. Konopka-Anstadt, J.L.; Mainou, B.A.; Sutherland, D.M.; Sekine, Y.; Strittmatter, S.M.; Dermody, T.S. The Nogo receptor NgR1 mediates infection by mammalian reovirus. Cell Host Microbe 2014, 15, 681-691. [CrossRef] [PubMed]

138. Liao, H.; Duka, T.; Teng, F.Y.H.; Sun, L.; Bu, W.Y.; Ahmed, S.; Tang, B.L.; Xiao, Z.C. Nogo-66 and myelin-associated glycoprotein (MAG) inhibit the adhesion and migration of Nogo-66 receptor expressing human glioma cells. J. Neurochem. 2004, 90, 1156-1162 [CrossRef] [PubMed]

139. Kang, Y.H.; Han, S.R.; Jeon, H.; Lee, S.; Lee, J.; Yoo, S.M.; Park, J.B.; Park, M.J.; Kim, J.T.; Lee, H.G.; et al. Nogo receptor-vimentin interaction: A novel mechanism for the invasive activity of glioblastoma multiforme. Exp. Mol. Med. 2019, 51, 1-15. [CrossRef] [PubMed]

140. Papachristodoulou, A.; Silginer, M.; Weller, M.; Schneider, H.; Hasenbach, K.; Janicot, M.; Roth, P. Therapeutic targeting of TGFb ligands in glioblastoma using novel antisense oligonucleotides reduces the growth of experimental gliomas. Clin. Cancer Res. 2019, 25, 7189-7201. [CrossRef]

141. Strong, J.E.; Coffey, M.C.; Tang, D.; Sabinin, P.; Lee, P.W.K. The molecular basis of viral oncolysis: Usurpation of the Ras signaling pathway by reovirus. EMBO J. 1998, 17, 3351-3362. [CrossRef]

142. Norman, K.L.; Hirasawa, K.; Yang, A.D.; Shields, M.A.; Lee, P.W.K. Reovirus oncolysis: The Ras/RalGEF/p38 pathway dictates host cell permissiveness to reovirus infection. Proc. Natl. Acad. Sci. USA 2004, 101, 11099-11104. [CrossRef]

143. Marcato, P.; Shmulevitz, M.; Pan, D.; Stoltz, D.; Lee, P.W.K. Ras transformation mediates reovirus oncolysis by enhancing virus uncoating, particle infectivity, and apoptosis-dependent release. Mol. Ther. 2007, 15, 1522-1530. [CrossRef] [PubMed]

144. Twigger, K.; Roulstone, V.; Kyula, J.; Karapanagiotou, E.M.; Syrigos, K.N.; Morgan, R.; White, C.; Bhide, S.; Nuovo, G.; Coffey, M.; et al. Reovirus exerts potent oncolytic effects in head and neck cancer cell lines that are independent of signalling in the EGFR pathway. BMC Cancer 2012, 12, 368. [CrossRef] [PubMed]

145. Alain, T.; Kim, T.S.Y.; Lun, X.Q.; Liacini, A.; Schiff, L.A.; Senger, D.L.; Forsyth, P.A. Proteolytic disassembly is a critical determinant for reovirus oncolysis. Mol. Ther. 2007, 15, 1512-1521. [CrossRef] [PubMed]

146. Morris, D.; Tu, D.; Tehfe, M.A.; Nicholas, G.A.; Goffin, J.R.; Gregg, R.W.; Shepherd, F.A.; Murray, N.; Wierzbicki, R.; Lee, C.W.; et al. A Randomized Phase II study of Reolysin in Patients with Previously Treated Advanced or Metatstatic Non Small Cell Lung Cancer (NSCLC) receiving Standard Salvage Chemotherapy-Canadian Cancer Trials Group IND 211. J. Clin. Oncol. 2016. [CrossRef] 
147. Cohn, D.E.; Sill, M.W.; Walker, J.L.; Malley, D.O.; Nagel, C.I.; Rutledge, T.L.; Bradley, W.; Richardson, D.L.; Moxley, K.M.; Aghajanian, C. Randomized phase IIB evaluation of weekly paclitaxel versus weekly paclitaxel with oncolytic reovirus (Reolysin ${ }^{\circledR}$ ) in recurrent ovarian, tubal, or peritoneal cancer: An NRG Oncology/Gynecologic Oncology Group study. Gynecol. Oncol. 2017, 146, 477-483. [CrossRef] [PubMed]

148. Barton, K.L.; Misuraca, K.; Cordero, F.; Dobrikova, E.; Min, H.D.; Gromeier, M.; Kirsch, D.G.; Becher, O.J. PD-0332991, a CDK4/ 6 inhibitor, significantly prolongs survival in a genetically engineered mouse model of brainstem glioma. PLoS ONE 2013. [CrossRef]

149. Desjardins, A.; Gromeier, M.; Herndon, J.E.; Beaubier, N.; Bolognesi, D.P.; Friedman, A.H.; Friedman, H.S.; McSherry, F.; Muscat, A.M.; Nair, S.; et al. Recurrent glioblastoma treated with recombinant poliovirus. N. Engl. J. Med. 2018, 379, 150-161. [CrossRef] [PubMed]

150. Gromeier, M.; Brown, M.C.; Zhang, G.; Lin, X.; Chen, Y.; Wei, Z.; Beaubier, N.; Yan, H.; He, Y.; Desjardins, A.; et al. Very low mutation burden is a feature of inflamed recurrent glioblastomas responsive to cancer immunotherapy. Nat. Commun. 2021. [CrossRef]

151. Geletneky, K.; Huesing, J.; Rommelaere, J.; Leuchs, B.; Capper, D.; Bartsch, A.J.; Neumann, J.O.; Schöning, T.; Hüsing, J.; Beelte, B.; et al. Phase I/IIa study of intratumoral/intracerebral or intravenous/intracerebral administration of Parvovirus H-1 (ParvOryx) in patients with progressive primary or recurrent glioblastoma multiforme: ParvOryx01 protocol. BMC Cancer 2012, 12, $3516-3523$. [CrossRef]

152. Geletneky, K.; Hajda, J.; Angelova, A.L.; Leuchs, B.; Capper, D.; Bartsch, A.J.; Neumann, J.O.; Schöning, T.; Hüsing, J.; Beelte, B.; et al. Oncolytic H-1 Parvovirus Shows Safety and Signs of Immunogenic Activity in a First Phase I/IIa Glioblastoma Trial. Mol. Ther. 2017, 25, 2620-2634. [CrossRef] [PubMed]

153. Di Piazza, M.; Mader, C.; Geletneky, K.; Herrero y Calle, M.; Weber, E.; Schlehofer, J.; Deleu, L.; Rommelaere, J. Cytosolic Activation of Cathepsins Mediates Parvovirus H-1-Induced Killing of Cisplatin and TRAIL-Resistant Glioma Cells. J. Virol. 2007, 81, 4186-4198. [CrossRef]

154. Guo, Z.S.; Lu, B.; Guo, Z.; Giehl, E.; Feist, M.; Dai, E.; Liu, W.; Storkus, W.J.; He, Y.; Liu, Z.; et al. Vaccinia virus-mediated cancer immunotherapy: Cancer vaccines and oncolytics. J. Immuno. Ther. Cancer 2019, 7, 1-21. [CrossRef] [PubMed]

155. Advani, S.J.; Buckel, L.; Chen, N.G.; Scanderbeg, D.J.; Geissinger, U.; Zhang, Q.; Yu, Y.A.; Aguilar, R.J.; Mundt, A.J.; Szalay, A.A. Preferential replication of systemically delivered oncolytic vaccinia virus in focally irradiated glioma xenografts. Clin. Cancer Res. 2012, 18, 2579-2590. [CrossRef] [PubMed]

156. Foloppe, J.; Kempf, J.; Futin, N.; Wallace, C.; Palmer, C.A.; Morris, D.; Cairncross, G.; Matthews, M.V.; Markert, J.; Gillespie, Y.; et al. The Enhanced Tumor Specificity of TG6002, an ArMed. Oncolytic Vaccinia Virus Deleted in Two Genes Involved in Nucleotide Metabolism. Mol. Ther. Oncolytics 2019, 14, 1-14. [CrossRef] [PubMed]

157. Zloza, A.; Kim, D.W.; Kim-Schulze, S.; Jagoda, M.C.; Monsurro, V.; Marincola, F.M.; Kaufman, H.L. Immunoglobulin-like transcript 2 (ILT2) is a biomarker of therapeutic response to oncolytic immunotherapy with vaccinia viruses. J. Immunother. Cancer 2014, 2, 1-8. [CrossRef]

158. Lee, N.H.; Kim, M.; Oh, S.Y.; Kim, S.G.; Kwon, H.C.; Hwang, T.H. Gene expression profiling of hematologic malignant cell lines resistant to oncolytic virus treatment. Oncotarget 2017, 8, 1213-1225. [CrossRef]

159. Balvers, R.K.; Kleijn, A.; Kloezeman, J.J.; French, P.J.; Kremer, A.; Bent MJVan Den Dirven, C.M.F.; Leenstra, S.; Lamfers, M.L.M. Serum-free culture success of glial tumors is related to specific molecular profiles and expression of extracellular matrix-associated gene modules. Neuro-Oncology 2013, 15, 1684-1695. [CrossRef] [PubMed]

160. Kleijn, A.; Kloezeman, J.J.; Balvers, R.K.; Kaaij MVan Der Dirven, C.M.F.; Leenstra, S.; Lamfers, M.L.M. A Systematic Comparison Identifies an ATP-Based Viability Assay as Most Suitable Read-Out for Drug Screening in Glioma Stem-Like Cells. Stem Cells Int. 2016, 2016. [CrossRef]

161. Pont, L.B.; Balvers, R.K.; Kloezeman, J.J.; Nowicki, M.O.; Van Den Bossche, W.; Kremer, A.; Wakimoto, H.; Van Den Hoogen, B.G.; Leenstra, S.; Dirven, C.M.F.; et al. In vitro screening of clinical drugs identifies sensitizers of oncolytic viral therapy in glioblastoma stem-like cells. Gene Ther. 2015, 22, 947-959. [CrossRef] [PubMed]

162. Dijkstra, K.K.; Cattaneo, C.M.; Weeber, F.; Chalabi, M.; van de Haar, J.; Fanchi, L.F.; Slagter, M.; van der Velden, D.L.; Kaing, S.; Kelderman, S.; et al. Generation of Tumor-Reactive T Cells by Co-culture of Peripheral Blood Lymphocytes and Tumor Organoids. Cell 2018, 174, 1586-1598. [CrossRef]

163. Grill, J.; Lamfers, M.L.M.; van Beusechem, V.W.; Dirven, C.M.; Pherai, D.S.; Kater, M.; Van der Valk, P.; Vogels, R.; Vandertop, W.P.; Pinedo, H.M.; et al. The Organotypic Multicellular Spheroid Is a Relevant Three-Dimensional Model to Study Adenovirus Replication and Penetration in Human Tumors in Vitro. Mol. Ther. 2002, 6, 609-614. [CrossRef] [PubMed]

164. Burton, C.; Das, A.; McDonald, D.; Vandergrift, W.A., III.; Patel, S.J.; Cachia, D.; Bartee, E. Oncolytic myxoma virus synergizes with standard of care for treatment of glioblastoma multiforme. Oncolytic Virotherapy 2018, 7, 107-116. [CrossRef] [PubMed]

165. Sood, D.; Tang-Schomer, M.; Pouli, D.; Mizzoni, C.; Raia, N.; Tai, A.; Arkun, K.; Wu, J.; Black, L.D.; Scheffle, B.; et al. 3D extracellular matrix microenvironment in bioengineered tissue models of primary pediatric and adult brain tumors. Nat. Commun. 2019, 10, 1-14. [CrossRef] [PubMed]

166. Robertson, F.L.; Marqués-Torrejón, M.A.; Morrison, G.M.; Pollard, S.M. Experimental models and tools to tackle glioblastoma. DMM Dis. Model Mech. 2019, 12. [CrossRef] 
167. Cai, X.; Briggs, R.G.; Homburg, H.B.; Young, I.M.; Davis, E.J.; Lin, Y.H.; Battiste, J.D.; Sughrue, M.E. Application of microfluidic devices for glioblastoma study: Current status and future directions. Biomed. Microdevices 2020, 22, 1-10. [CrossRef]

168. Jacob, F.; Salinas, R.D.; Zhang, D.Y.; Nguyen, P.T.T.; Schnoll, J.G.; Wong, S.Z.H.; Thokala, R.; Sheikh, S.; Saxena, D.; Prokop, S.; et al. A Patient-Derived Glioblastoma Organoid Model and Biobank Recapitulates Inter- and Intra-tumoral Heterogeneity. Cell 2020, 180, 188-204. [CrossRef] [PubMed]

169. Kemp, V.; Lamfers, M.L.M.; Pluijm, G.; Van Der Hoogen, B.G.; Van Den Hoeben, R.C. Developing oncolytic viruses for clinical use: A consortium approach. Cytokine Growth Factor Rev. 2020. [CrossRef] 